\title{
The Procedure for Amending the Satversme of the Republic of Latvia and the Substance of Restrictions Established by It
}

\author{
Dr. iur. Ringolds Balodis \\ Faculty of Law, University of Latvia \\ Professor at the Department of Constitutional and Administrative Law \\ E-mail: Ringolds.Balodis@lu.lv
}

The article is dedicated to the mechanism for protecting the Satversme [Constitution] of the Republic of Latvia (hereafter - the Satversme) - procedure for amending it and elements thereof restrictions (quotas of participation, approval, readings, etc.), examining the amendments to the general and basic articles, as well as the theory of core. The parliament and the people may amend the Satversme in a referendum, therefore the article also turns briefly to the institution of the people's vote or plebiscite or referendum (Latin - referendum). The article aims to elucidate the effectiveness of the procedure for amending the Satversme and provide answers to the following questions: (1) Whether the procedure for amending the Satversme ensures protection of the national constitutional order on sufficient level and does not permit introduction into the Satversme of ill-considered or antidemocratic proposals; (2) Whether the legislator, aiming to ensure constitutional stability, has not set the exaggeratedly high quorum of voters' participation in the referendum for all articles of the Satversme and whether the mechanism of referendum in Latvia has not become incapable of functioning? In the framework of the article, the author also will try to reach concrete proposals that would improve the procedure for amending the Satversme, would increase citizens' involvement in the matters of public administration, which, in turn, would reinforce the people's trust in their State. In considering the proposals, the author will focus also on the issue of national security because amendments to the Satversme and referendums, clearly, may be used as factors for destabilising the State.

Keywords: Satversme [Constitution], restrictions to amending constitutions, amendments to Satversme, procedure for amending Satversme, basic articles of Satversme, core of Satversme, referendum, participation and approval quorums in a referendum.

\section{Contents}

Introduction ................................ 22

1. General Procedure for Amending the Satversme . . . . . . . . . . . . . 25

1.1. Circle of Subjects with the Right to Initiate Amendments to the Satversme . . . . 25

1.2. Number of Qualified Members of the Saeima at the Sitting Examining

Draft Amendments to the Satversme . . . . . . . . . . . . . 26

1.3. Procedure of Readings for a Draft Amendment to the Satversme . . . . . . . . 27

1.4. Other Provisions . . . . . . . . . . . . . . . . . . . . . 28

2. Mandatory Constitutional Referendum - the People's Right

to Express Their Assessment of the Satversme . . . . . . . . . . . . . . 28

2.1. The People's Safeguard of the Amendments to the Norms

Enumerated in Article 77 of the Satversme . . . . . . . . . . . . . . . 28 
2.2. The Right of the Totality of Citizens to Decide on Amendments

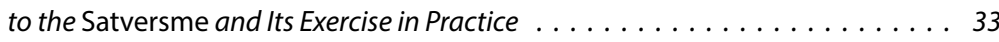

2.3. On the Constitutional Quorum Set for Amending the Satversme

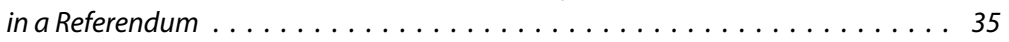

3. Improving the Procedure for Amending the Satversme . . . . . . . . . . 39

3.1. Reflecting on the Statements Made by Jänis Rainis, the Member of the Constitutional Assembly, About Burgeois Fear of the National Referendums . . . 39

3.2. Proposals for Improving the Procedure for Amending the Satversme. . . . . . . 42

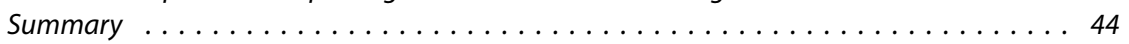

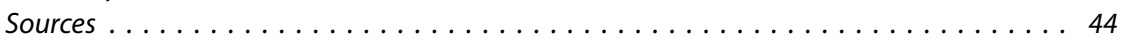

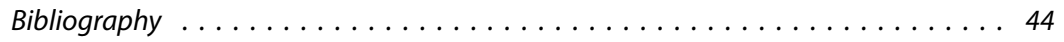

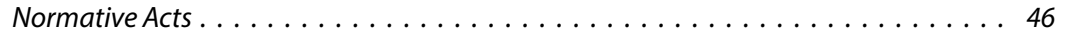

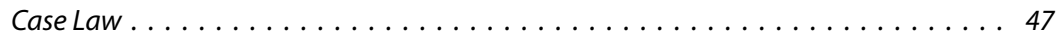

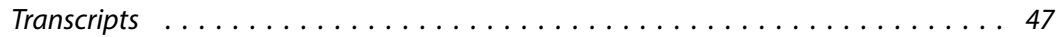

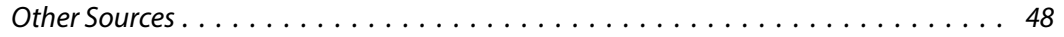

\section{Introduction}

The Republic of Latvia was proclaimed on 18 November $1918 .{ }^{1}$ The Satversme [Constitution] of the Republic of Latvia (hereafter - the Satversme) was adopted by the democratically elected Constitutional Assembly on 15 February $1922,{ }^{2}$ following the authoritarian coup, organised by Kārlis Ulmanis, the Satversme was suspended on 15 May 1934 and later, during the years of occupation by Nazi Germany and the Soviet Union, existed only de iure until the basic articles of the Satversme were reinstated de facto when, on 4 May 1990, the transitional parliament of the Republic of Latvia Augstākā padome (the Supreme Council) adopted the Declaration of Independence ${ }^{3}$ and later also defined in the constitutional law ${ }^{4}$ that the Satversme determined the status of the restored State of Latvia. The full functioning of the Satversme on the territory of Latvia was renewed by the first convocation of the Saeima elected after the restoration of independence by the special announcement of 6 July 1993. ${ }^{5}$ The first convocation of the Saeima of restored Latvia was able to set up, within a couple of months, a functioning system of the bodies of the State power, and legal regulation, envisaged in the Satversme. ${ }^{6}$ Already within a year following its reinstatement, the Satversme was amended. At the time of writing this article - autumn of 2020 - the Satversme had been amended, in total, fifteen times.

1 Latvijas pilsoniem!: Tautas Padomes Latvijas Republikas proklamēšanas akts [For Latvian citizens!: Proclamation Act of the People's Council of Latvia] (18.11.1918). Latvijas Pagaidu Valdibas Likumu un Rīkojumu Krājums, No. 1, 15.07.1919.

2 Latvijas Republikas Satversme [Satversme [Constitution] of the Republic of Latvia] (15.02.1922). Valdïbas Vēstnesis, No. 141, 1922.

3 Par Latvijas Republikas neatkarības atjaunošanu: Augstākās padomes deklarācija [On the restoration of independence of the Republic of Latvia: Declaration of the Supreme Council] (04.05.1990). Latvijas Republikas Augstākās Padomes un Valdības Ziņotājs, No. 20, 17.05.1990.

4 Par Latvijas Republikas valstisko statusu: konstitucionālais likums [On the State status of the Republic of Latvia: constitutional law] (21.08.1991). Latvijas Republikas Augstākās Padomes un Valdības Ziņotājs, No. 42, 24.10.1991.

5 Latvijas Republikas Saeimas pazinojums [Statement by the Saeima of the Republic of Latvia]. Latvijas Republikas Saeimas un Ministru Kabineta Ziņotājs, No. 30, 14.10.1993.

6 Kusin̨š, G. Valsts iekārtas un tiesibu sistēmas atjaunošana [Renewal of the national equipment and legal system]. In: Latvijas Valsts tiesību avoti. Valsts dibināšana - neatkarības atjaunošana. Dokumenti un komentäri [Sources of Latvian State Law. Establishment of the state - restoration of independence. Documents and comments]. Rīga: Tiesu namu aǵentūra, 2015, p. 238. 
Except the first amendment to the Satversme (1933), all others were adopted after the restoration of independence. On all occasions, the amendments to the Satversme were initiated by the members of the Saeima and were approved by the Saeima, whereas all attempts to amend the Satversme through a referendum have failed. It must be noted that, following the restoration of independence, certain regularity in the adoption of amendments to the Satversme can be observed, which is, on average, one amendment per two years. Amendments to the basic law of the Latvian State have increased its original length ${ }^{7}$ by one third, although, regardless of this, the Satversme has been able to retain its status of a concise document.

The primary object of research for this article is ratio legis of the procedure for amending the Satversme, therefore, before examining it, it seems that insight into the genesis of the Satversme would be useful. The formula for amendments, which has remained unchanged since its beginnings, as well as, inter alia, the basic provisions regarding a referendum were created by the Constitutional Assembly. In 1921, after hearing most diverse proposals regarding the procedure for amending the Satversme ${ }^{8}$ decided in favour of the proposal made by a member of the small German faction ${ }^{9}$ Paul Schiemann. The proposal made by the German-speaking member of the Constitutional Assembly was based on the norms of 1919 Weimar Constitution $^{10}$ and was founded on the concept that amending the constitution should be sufficiently burdensome for it not to be implemented too often; however, it should be flexible enough, allowing the parliament, if necessary, to do that. As regards the involvement of the people in amending the Satversme, Schiemann was guarded, expressing the opinion that the people should be involved in the process of amending the constitution "only in exceptional, definite cases"11, moreover, "saspīlējot tās [tautas] gribu" - "constraining its [the people's] will" by a high quorum. ${ }^{12}$ Taking into account even only the experience of Latvia and the tragedy of the Baltic Germans (loss of former titles, immense estates and power, etc.), P. Schiemann's attitude (regarding the high quorum) is understandable; however, the unanimous support by the civic parties and leftist parties for this procedure is surprising. Thus, for instance, at the sitting, Jānis Purgailis fully reiterates Pauls Schiemann's position - the people should participate in the referendum "being entirely prepared with clear conviction, clear awareness that such acts should occur only in cases of serious need" and therefore a high quorum for approval is needed.

7 The initial (historical) text of the Satversme was 2265 words long, whereas now (on 1 November 2020) it has reached the length of 3415 words. The major part of it is constituted by amendments No. 5 to the Satversme of 1998, which added to the Satversme a new chapter - Chapter VIII with 28 articles, and amendments No. 13 to the Satversme of 2014, which replaced the original (initial) Preamble to the Satversme with a new one.

8 See more Balodis, R., Kuznecovs, A. Satversmes 76. panta komentārs [Comment of Article 76 of the Satversme]. In: Latvijas Republikas Satversmes komentāri. V nodal̦a. Likumdošana [Comments of Satversme [Constitution]. Section V. Legislation]. Collective of authors, scientific ed. Prof. Balodis, $R$. Rīga: Latvijas Vēstnesis, 2019, pp. 201-203.

9 The Constitutional Assembly consisted of one hundred and fifty members, whereas the German faction had only five members.

10 See Article 74, 75 and 76 of the Constitution of the German Reich August 11, 1919. Available: http://hydrastg.library.cornell.edu/fedora/objects/nur:01840/datastreams/pdf/content [last viewed 10.09.2020].

11 Latvijas Republikas IV Saeimas V sesijas 4. sēdes (1933. gada 10. februārī) stenogramma [Transcript of the $4^{\text {th }}$ sitting of the V Session of the Latvian IV Saeima [Parliament] 10.02.1933]. In: Latvijas Republikas IV Saeimas V sesija. 1933. gads. [Session of the Latvian IV Saeima V sitting. Rìga: Latvijas Republikas Saeimas izdevums, 1933, p. 149.

12 Ibid. 
Most probably, in fear of confrontational legislative initiatives of the voters ${ }^{13}$, Purgailis dismisses doubts regarding the exaggerated size of the quorum, stating that, if the issue to be examined in a referendum were important for the people then the required "number of participants would arise and the referendum will be able to take place" "14, and the same is stated also by Cielēns, who is one of the true architects of the Satversme, adopted on 15 February 1922, because he heads the first sub-committee of the Committee for Drafting the Satversme. ${ }^{15}$

At the sub-committee of the Committee for Drafting the Satversme of the Constitutional Assembly (1921), the initial proposal by Paul Schiemann is split into several norms of Satversme, until finally the current numbering is established (76, 77, 78 and 79) ${ }^{16}$ In this interconnected set of articles, Article 76 defines the general (ordinary) procedure for amending the Satversme, Article 78 sets out the procedure, in which the people (totality of citizens) can initiate amendment to the Satversme, whereas the first part of Article 79 defines the quorum for approving the amendments to the Satversme put for a national referendum. To add, in the wording of the Satversme adopted by the Constitutional Assembly, Article 79 did not have the second part, it was amended by the amendments to the Satversme of 1933 and again - in 2003. Currently, the second part of Article 79 defines the quorum of voters and the simple majority vote required to adopt a law or a decision with respect the membership of the State of Latvia in the European Union.

76. The Saeima may amend the Constitution in sittings at which at least two-thirds of the members of the Saeima participate. The amendments shall be passed in three readings by a majority of not less than two-thirds of the members present.

77. If the Saeima has amended the first, second, third, fourth, sixth or seventyseventh Article of the Constitution, such amendments, in order to come into force as law, shall be submitted to a national referendum.

78. Electors, in number comprising not less than one tenth of the electorate, have the right to submit a fully elaborated draft of an amendment to the Constitution or of a law to the President, who shall present it to the Saeima. If the Saeima does not adopt it without change as to its content, it shall then be submitted to national referendum.

79. An amendment to the Constitution submitted for national referendum shall be deemed adopted if at least half of the electorate has voted in favour. A draft law, decision regarding membership of Latvia in the European Union or substantial changes in the terms regarding such membership submitted for national referendum shall be deemed adopted if the number of voters is at least

13 Rodina, A. Valstiskuma pamatu aizsardzības mehānismi [Mechanisms for Protecting the Foundations of Statehood]. In: Latvijas Universitātes 71. zinātniskās konferences rakstu krājums. Tiesību interpretācija un tiesỉbu jaunrade - kā rast pareizo lïdzsvaru [The $71^{\text {st }}$ Scientific Conference of the University of Latvia. The interpretation of rights and the creation of rights - how to find the right balance]. Rīga: Latvijas Universitāte, 2013, p. 222.

14 Rainis, J. Vispārējās debates par Satversmes I daḷu. IV sesijas 5. sēdes (1921. gada 28. septembrī) stenogramma. [Transcript of the $5^{\text {th }}$ sitting of the IV Session of the Constitutional Assembly 28.09.1921]. In: Latvijas Satversmes sapulces stenogrammu izvilkums (1920-1922). Latvijas Republikas Satversmes projekta apspriešana un apstiprināšana [Discussion and approval of the draft Constitution of the Republic of Latvia]. Rīga: Tiesu namu aǵentūra, 2006, p. 129.

15 Ibid.

16 Latvijas Satversmes sapulces Satversmes komisijas 1. apakškomisijas 1921. gada 17. janvāra sēdes protokols Nr. 8 [Minutes of the Constitutional Assembly Constitutional Commission $1^{\text {st }}$ subcommission meeting 17.01.1921], unpublished material. 
half of the number of electors as participated in the previous Saeima election and if the majority has voted in favour of the draft law, membership of Latvia in the European Union or substantial changes in the terms regarding such membership.

Prior to commencing more detailed examination of the regulation, it must be noted that the Latvian basic law should be counted as one of the flexible ${ }^{17}$ constitutions $^{18}$ of the group of "strict" constitutions, because a number of states in this group have embedded more substantial restrictions to amending the constitution in their constitutions (e.g., the US, Australia, Japan, etc.)

\section{General Procedure for Amending the Satversme}

More than a hundred years ago, Professor Kārlis Dišlers, examining the procedure for amending the Satversme, arrives at the conclusion that a sufficiently clear borderline between the ordinary and the constitutional legislation had not been drawn, ${ }^{19}$ at the same time, as mentioned in the previous section, some elements of amendments are defined in some articles of the Satversme. Article 76 of the Satversme includes the basic restrictions to amending the Satversme. Let us examine these elements from the vantage point of comparative constitutional law, choosing as the basis the typical restrictions pertaining to constitutions of unitary, unicameral republics, defined in constitutions for republics with unicameral parliament. For this purpose, they are divided by the (1) range of subjects who initiate amendments to the constitution; (2) quorums that are required in parliaments for the approval of the constitutions; (3) the procedure for reading the draft amendments to the constitution; (4) other provisions. ${ }^{20}$

\subsection{Circle of Subjects with the Right to Initiate Amendments to the Satversme}

Amendments to the Satversme may be proposed by the same subjects, ${ }^{21}$ who have the right to do it in the legislative process.

65. Draft laws may be submitted to the Saeima by the President, the Cabinet or committees of the Saeima, by not less than five members of the Saeima, or, in accordance with the procedures and in the cases provided for in this Constitution, by one-tenth of the electorate.

As mentioned above, disregarding the states with bicameral parliaments or/ and federal system because initiation of constitutional amendments and the very process of amending is much more complicated, it must be noted that proposing amendments to the Satversme in Latvia is rather simple. There are countries where amendments to the constitutions may be initiated by a much more limited number of subjects compared to amendments to ordinary laws (for instance, in

17 Endziņ̌s, A. Preambulas projekts var destabilizēt sabiedrību [The draft preamble could destabilize society.] Jurista Värds, No. 44, 29.10.2013, pp. 6-7.

18 Balodis, R. Latvia. In: Encyclopedia of World Constitutions. Vol. II. Ed. Robbers, G. U.S. Facts on File, 2007, p. 514.

19 Dišlers, K. Latvijas Republikas Satversmes grozišanas kārtība [Procedures for amending the Satversme [Constitution] of the Republic of Latvia]. Tieslietu Ministrijas Vēstnesis, No. 7/8, 1929, pp. 227-228.

20 See more Balodis, R., Kuznecovs, A. Satversmes 76. panta komentārs [Comment of Article 76 of the Satversme], pp. 201-203.

${ }^{21}$ Balodis, $R$. The Constitution of Latvia. In: Rechtspolitisches Forum Legal Policy Forum Institut für Rechtspolitik an der Universität Trier, No. 26, 2004, p. 23. 
Estonia, ${ }^{22}$ it is only one-tenth of the members of the parliament and the president), in some countries a larger number of the members of the parliament is required (for instance, three-fourths in Bulgaria ${ }^{23}$ or one-fifth in Croatia $\left.{ }^{24}\right)$.

In Latvia, all draft laws reach the Presidium of the Saeima, which puts the on the agenda of the Saeima's sitting for examination. The Saeima decides on transferring the draft law to a committee or dismissing it. The Saeima's vote on transferring it to the committee is not to be regarded as a reading in the meaning of Article 76 of the Satversme, therefore, at the sitting the decisions is adopted by "klätesošo deputātu absolüto balsu vairākumu" ("an absolute majority of votes of the members present at the sitting") according to the Article 24 of the Satversme. If the majority of the members of the Saeima has decided on dismissing the draft law, it is no longer proceeded with, if it is supported, it goes to the respective committee ${ }^{25}$ (usually, the Legal Committee), which is obliged to prepare an opinion, annotation ${ }^{26}$ and advance it for the reading at the Saeima. During this "zero reading", only two members may speak, each of them is given five minutes to present their opinion, and one has to be "in favour of", while the other - "against" the draft law.

\subsection{Number of Qualified Members of the Saeima at the Sitting Examining Draft Amendments to the Satversme}

In amending the Satversme of the Republic of Latvia, the quorums of the members present and of approval must be complied with. Article 76 of the Satversme defines the same proportion for both quorums - two-thirds. Namely, for the sitting for amending the Satversme to be legitimate, at least 67 members must participate in it, which is two-thirds or the absolute majority of the members of the Saeima. The quorum for approving amendments to the Satversme, as opposed to the participation quorum, is a variable because it depends on the number of members who attend the sitting and have registered. With increasing number of members present, the quorum of approval also increases in arithmetic progression (for instance, with 67 members present, the approval quorum will be 45 members, with 87 members present, the approval quorum will be 58 members, with 91 members present, the approval quorum will be 61 members, etc.). The Latvian Saeima, just like many other parliaments in the world, uses the electronic voting system; therefore, to verify the qualified majority, the Presidium of the Saeima holds registration to establish the presence of members. Pursuant to Article 15 (2) of the Rules of Procedure of the Saeima, the member's presence in the sitting is established by his or her last registration for a quorum.

22 See, for example, Article 103 and 161 of the Estonian Constitution. Available: https://www.constitute project.org/constitution/Estonia_2015.pdf?lang=en [last viewed 04.09.2020].

23 See Article 154 of the Bulgarian Constitution. Available: https://www.constituteproject.org/ constitution/Bulgaria_2015?lang=en [last viewed 04.09.2020].

24 See Article 136 Croatia’s Constitution. Available: https://www.constituteproject.org/constitution/Croatia_2013?lang=en [last viewed 04.09.2020].

25 See Article 82, part one. Saeimas kārtỉbas rullis: LR likums [The Rules of Procedure of the Saeima: Law of the Republic of Latvia], Article 81. Latvijas Vēstnesis, No. 96(227), 18.08.1994.

26 Ibid., Article 86, part 2. 


\subsection{Procedure of Readings for a Draft Amendment to the Satversme}

Abiding by the procedure set for the adoption of a legal norm is the precondition for the validity of a legal norm, ${ }^{27}$ which the legislator always must comply with. In amending constitutions, particularly strict adherence to this procedure is required because the national basic law constitutes the legal foundations of the whole legal system and contesting the legitimacy of a norm of the basic law may seriously undermine the citizens' trust in democracy.

"The provision of three readings" is included in Article 76 of the Latvian Satversme, which is linked to "the impossibility of urgency principle". ${ }^{28}$ It is included in the Satversme to prevent rushing the procedure of amendments by using the institute of urgency, when, pursuant to Article 75 of the Satversme, draft laws are adopted with two-thirds of the votes of members present in two readings. It is generally considered that the discussion of a draft law in three readings allows adopting a better-considered constitutional norm, whereas two readings entail a greater probability of flawed legislation. At the same time, a definite interval of time between the reading has not been determined in Latvia, as in the Estonian Constitution $^{29}$, referred to above, where, similarly to Latvia, draft constitutional amendments are discussed by the Parliament (Riigikogu); however, the interval between the first and the second reading is at least three months and the interval between the second and the third reading is at least one month. Thus, the shortest possible interval between the first and the third reading is at least four months. ${ }^{30}$ It must be added that the Estonian Constitution, which was adopted in 1992, has been amended only five times. ${ }^{31}$ In countries with bicameral parliament, for instance, in Italy, ${ }^{32}$ amendments to the Constitution must be discussed by both chambers and the periods between the readings must be at least three months, etc. A procedure like this has not been established in Latvia, and sometimes amendments to the Satversme have been adopted even within a month and a half. For instance, in the spring of 2009, the fourteenth amendments to the Satversme recast Article 14 of the Satversme within a month a half. The Saeima decided to transfer the draft law to the committee at the sitting of 15 March 2009, the first reading was held at the sitting of 4 April, the second - at the sitting of 19 April, but the third - at the sitting of 3 May. The last, fifteenth amendments to the Satversme (2018) are even a more striking example, amending the procedure for electing the President of the State, established in Article 36 of the Satversme (from secret to open), two days before the parliamentary election. The Saeima decided to transfer the draft law to the committee at the sitting of 17 May 2018, the first reading was held at the sitting of 6 September 2018, the second - in the next month, at the sitting of 20 September, but the third - at the sitting of 4 October, whereas the election of the $13^{\text {th }}$ convocation of the Saeima was held on 6 October. Constitutional barriers are established in constitutions to minimise hasty amendments based on emotions or populism. Amendments to the Satversme, which are adopted demonstratively on

27 Judgment of 24 October 2019 by the Constitutional Court in case No. 2018-23-03, para. 14.

28 Balodis, R., Kuznecovs, A. Satversmes 76. panta komentārs [Comment of Article 76 of the Satversme], p. 214.

29 See, for example, Article 163 Estonia Constitution. Available: https://www.constituteproject.org/ constitution/Estonia_2015.pdf?lang=en [last viewed 04.09.2020].

30 Narits, R., Merusk, K. Constitutional Law. Estonia. The Hague, London, Boston: Kluwer, 1998, p. 58.

31 http://www.baltic-course.com/eng/analytics/?doc=105865 [last viewed 04.09.2020].

32 See Article 154 of the Italian Constitution. Available: https://www.constituteproject.org/constitution/ Italy_2012?lang=en [last viewed 04.09.2020]. 
the eve of the parliamentary election, when all kinds of political canvassing are prohibited, provide grounds for reflections that it is not sufficient to have only the provision of three readings, setting a time interval between the readings should also be considered. The use of amendments to the Satversme in the pre-election passions should be reduced to the minimum.

\subsection{Other Provisions}

Among other provisions, it should be noted that, in the course of examining ordinary draft laws, proposals for new amendments can be advanced also for the second and the third reading, whereas with respect to amendments to the Satversme this procedure is not allowed. This prohibition has been established to prevent a situation where the proposals are poorly discussed and analysed. This has been recognised by the Constitutional Court ${ }^{33}$, pointing out that proposals may be submitted only with respect to those articles (regarding amending or deleting these articles), which had been included in the draft law when it was adopted in the first reading. There are countries (for instance, Lithuania), where the constitution cannot be amended ${ }^{34}$ if martial law has been proclaimed in the country, the situation is similar in France, where the procedure for amending the constitution is not initiated or it is stayed if an emergency state is announced, which is linked to a threat to the integrity of the national territory. ${ }^{35}$ In the Latvian procedure for amending the Satversme, nothing is said about the procedure in states of emergency and exceptional situations, why it would be possible in practice. I believe that the statement made by Arvìds Dravnieks that "self-evident practice of contemporary Western democracy is that the parliament of one conscription does not introduce substantial constitutional amendments" ${ }^{36}$ merits a more detailed analysis. Restrictions of this type are practiced by Portugal and Sweden, and I believe that it could be a good tool for slowing down the advancement of amendments to the Satversme to reconsider them, possibly, after emotions have settled.

\section{Mandatory Constitutional Referendum - the People's Right to Express Their Assessment of the Satversme}

\subsection{The People's Safeguard of the Amendments to the Norms Enumerated in Article 77 of the Satversme}

In Latvia, amendments to the Satversme may be adopted by both constitutional legislators - the Saeima, in the procedure established in Article 76 of the Satversme, and the totality of citizens, in the procedure established in Article 78 of the Satversme. If the Saeima, as the constitutional legislator, has amended the articles enumerated in Article 77 of the Satversme, i.e., Articles 1, 2, 3, 4, 6 or 77, ${ }^{37}$ for

33 Judgment of 16 December 2008 by the Constitutional Court in case No. 2008-09-0106, para. 16.5.

34 See Article 147 of the Lithuanian Constitution. Available: https:/www.constituteproject.org/ constitution/Lithuania_2006?lang=en [last viewed 04.09.2020].

35 See Article 89 of the French Constitution. Available: https://www.constituteproject.org/constitution/ France_2008?lang=en [last viewed 04.09.2020].

36 Priekšlikumi Latvijas publiskās varas pilnveidošanai Ekspertu grupas pārvaldības pilnveidei materiāli [Proposals for improving the public governance of Latvia. Materials for improving the management of the expert group]. Rìga: Latvijas Vēstnesis, 2015, p. 215.

37 It must be added that, initially, Article 4 and also Article 7 itself were not included in the enumeration of the basic articles of the Satversme. With the intention of reinforcing the official language, in 1998, the $6^{\text {th }}$ convocation of the Saeima amended Article 4, including in it the official language, and included this recast article in the enumeration of Article 77. The amendment made by the $6^{\text {th }}$ convocation of 
the amendment to enter into force it must be approved by the other constitutional legislator - the people, doing this in a referendum. Professor Kārlis Dišlers named this procedure "tautas apsardzibu" ("the people's safeguard"), ${ }^{38}$ because the parliament itself does not have an independent possibility to amend these basic articles of the Satversme - the people must have the final say. The next section of the article will examine the practical implementation of the law on the people's referendum, which applies to safeguarding the basic articles of the Satversme. ${ }^{39}$ It envisages the possibility, in special cases ${ }^{40}$, to turn to the nation's collective reason to receive the final conclusion. This constitutional regulation must be examined in interconnection with the Constitutional Court's finding that provides that the national referendums in the procedure set out in Article 77 of the Satversme must be held also if the parliament, amending a legal act "substantially", also affects legal norms that are protected by the said article of the Satversme, for instance, adopting a law on the ratification of an international agreement, which infringes on the provisions of Article 1 and Article 2 of the Satversme. ${ }^{41}$ Also in such a case, a referendum must be held, as in the case if the Saeima had amended the very norms enumerated in Article 77 of the Satversme. Likewise, the Constitutional Court has recognised that, in amending laws or the Satversme, the Saeima's discretion is limited to a certain extent because the parliament, in making decisions, must take into account several factors that it may not ignore. These factors are, for instance, the European Union Law, general principles of law and other norms of the Satversme.42 In this context, the issue arises regarding the "concept of the Satversme's core", which was extensively discussed in the circles of lawyers and politicians following publication of the opinion by the Constitutional Law Committee under the President's Auspices ${ }^{43}$ (2012). ${ }^{44}$

Professor, Senator of the Supreme Court Jautrite Briede, in explaining the Satversme, notes that none of the legislators may annex Latvia to another state or wish to review the basic decision included in the proclamation act of 18 November

the Saeima included Article 77 itself in Article 77, its becoming a basic article of the Saeima, substantially, closed their recasting in the future because the requirements with respect to the mandatory constitutional referendum are applied also to Article 77 itself.

38 Dišlers, K. Ievads Latvijas valststiesibu zinātnē [Introduction to the Science of Latvian State Law]. Rìga: Tiesu namu aǵentūra, 2017, p. 143.

39 Such substantial restriction is envisaged to preclude the possibility for the Saeima to decide unilaterally on the most important articles of the Satversme. I.e., if such political forces were to be in the parliament, who could ensure the quorums defined in Article 76, the amendments to the Satversme adopted by them that would change the political system or would otherwise undermine the foundations of the statehood would not enter into effect because they would have to be put for national referendum.

40 Clearly, amending the basic articles, enumerated in Article 77 of the Satversme, is a special case.

41 Judgment of 7 April 2009 by the Constitutional Court in case No. 2008-35-01, para. 15.1, 15.2.

42 Judgment of 18 April 2019 by the Constitutional Court in case No. 2018-16-03, para. 15.1.1.

43 The Constitutional Law Committee was established in 2007 by Preisdent Valdis Zatlers. Several wellknown lawyers were included in the Committee. Incumbent President Egils Levits was appointed its head, incumbent President of the Constitutional Court prof. Ineta Ziemele, current Justices of the Constitutional Court prof. Sanita Osipova, prof. Daiga Rezevska, Gunārs Kusin̦š, current Judge of the European Court of Human Rights Mārtiņš Mits and current Vice-Speaker of the Saeima Inese Lïbina-Egnere served on the Committee.

44 As became clear later, the actual "push" to draft a modern argumentative basis to substantiate the State, was the fact Chairperson of the Committee Egils Levits, invisible to the general society, personally turned to several important public officials. See Levits, E. Valstsgriba. Idejas un domas Latvijai 1985-2018 [National will. Ideas and thoughts for Latvia 1985-2018]. Rìga: Latvijas Vēstnesis, 2019, p. 560. 
1918 - Latvia is a sovereign and democratic state that respects human rights. ${ }^{45}$ Egils Levits explains this approach ${ }^{46}$ by the principle of "defensive democracy", otherwise a situation in Germany in 1933 could be repeated, when, by successive law-based actions, democratic structure was dismantled and replaced by the fascist regime. ${ }^{47}$ Such "legal revolution" would be inadmissible ${ }^{48}$ because an instantaneous democratic majority has neither the moral nor, since the adoption of the Preamble to the Satversme, legal right to deprive Latvians of the possibility to self-determine its statehood, which would be impossible to regain, once lost. ${ }^{49}$ I.e., the concept of the inviolable core of the Satversme does not permit "the State's suicide", so that one, separate amendment to the Satversme would not destroy the values, on which the Satversme is founded. ${ }^{50}$ An opinion has been voiced that the concept should be exercised only in the case of "extremely substantial" threat for the constitutional structure to defend the democratic order and prevent liquidation of a democratic state in seemingly correct procedural way. ${ }^{51}$ The concept of the core immediately acquired its supporters and opponents, ${ }^{52}$ just as the proposal to add to the Satversme a new Preamble, the wording of which "latviešu nācijas negrozāmā valstsgriba" ("the unwavering will of the Latvian nation to have its own State") reflects the concept of the inviolable core of the Satversme. ${ }^{53}$ Passions were aroused by the Preamble to the Satversme also during scientific conferences ${ }^{54}$ and articles ${ }^{55}$, and died down only after the sizeable Preamble, with the expanded core of the Satversme $e^{56}$, was included into the basic law. Clearly, it was great achievement by the Committee ${ }^{57}$ and also Egils Levits, proven by the fact that its recommendations were gradually approbated in practice. ${ }^{58}$ The Supreme Court has included the Committee's opinion in its judgements of 30 April 2013, 12 February 2014 and 28 March 2014. In its judgement of 30 April 2013, the Supreme Court expresses its support to the proposal, referred

45 Briede, J. Satversmes 78. panta komentārs [Comment of Article 78 of the Satversme], p. 286.

46 See Levits, E. Eiropas Savienība kā vērtību savienība [The European Union as a union of values]. Jurista Vārds, No. 19, 08.05.2018.

47 Levits, E. Valstsgriba ... [National will ...], pp. 565, 619, 638.

48 Ibid., p. 592.

49 Ibid., p. 835.

50 Pleps, J., Pastars, E., Plakane, I. Konstitucionālās tiesības [Constitutional law]. Supplemented and revised edition. Rīga: Latvijas Vēstnesis, 2014, p. 56.

51 Ibid.

52 Viedokḷu diskusija. Valsts pamati - vai visiem pašsaprotami [Discussion of views Discussion of views: State bases - or self-evident to all]. Jurista Vārds, No. 45, 06.11.2012, pp. 12-13, 15, 17, 19.

53 Meistere, D. Saeimas Juridiskā biroja atzinums par Satversmes ievada pieņemšanas procedūru [Opinion of the Saeima Legal Office on the procedure for the adoption of the Constitution Preamble]. Jurista Vārds, No. 26, 08.07.2014, pp. 12-13.

54 Aizritējusi konference par Satversmes preambulas paplašināšanas projektu [A conference on the draft extension of the preamble to the Constitution has elapsed]. Jurista Värds, No. 45, 05.11.2013, pp. 7-10.

55 See for example Endziņ̌̌, A. Preambulas projekts ... [The draft preamble ...], pp. 6-7.

56 Latvijas Republikas Satversmes komentāri. Ievads. I nodaḷa. Vispārējie noteikumi [Comments of Satversme. Section I. General rules]. Collective of authors, scientific ed. Prof. Balodis, R. Riga: Latvijas Vēstnesis, 2014, pp. 120-132.

57 Krūma, K., Plepa, D. Constitutional Law in Latvia. The Netherlands: Wolters Kluwer, 2016, p. 6.

58 It must be noted that not all proposals by the Committee have been implemented. One of the recommendations given by the Committee was to integrate into laws the right of the President, within a certain term before the promulgation of a law or an amendment to the Satversme, to turn to the Constitutional Court to establish, whether a law that had been adopted but had not been promulgated yet complied with the Satversme. 
to in the Committee's opinion ${ }^{59}$, regarding greater involvement of the Central Election Commission and the court (in assessing the elaborateness of the draft laws submitted for a referendum) and notes that the state institutions have incontestable right to prevent a threat to democracy already at an early stage.$^{60}$ In view of the fact that the text of the draft law, submitted by the initiative groups, cannot be changed in the further process, the Supreme Court notes in its judgement of 12 February 2014 that the Central Election Commission must ensure that a draft law that is contrary to the basic values of a democratic state governed by the rule of law should not be advanced for a referendum, ${ }^{61}$ whereas in its judgement of 28 March 2014, the Constitutional Court notes that for a draft amendment to the Satversme, initiated by the totality of citizens, to be considered as "pilnīgi izstrādātu" ("fully elaborated") as to its content, it may be incompatible either with those provisions of the Satversme that it does not propose to amend or with the core of the Satversme. ${ }^{62}$ The Supreme Court also explains in this judgement that part of the unwritten legal principles and basic values, on which the Satversme is founded, constitute the core of the Satversme. It includes all elements that form the identity of the State of Latvia and the identity of Latvia's order of a democratic state. ${ }^{63}$

It must be noted that even prior to the judgements referred to above, the Enterprise Register took the stand to safeguard the core of the Satversme, referring in its decisions to the Committee's findings as substantiation. The institution refused to register the party "Par dzimto valodu" ("For Native Language") because it identified in the party's programme, submitted for registration, turning against the foundations of the State - the Latvian language as the official language, as well as the territorial integrity of Latvia. ${ }^{64}$ Although there is no normative regulation with respect to the core, the Legal Bureau of the Saeima holds that the Saeima as the legislator recognises the inviolable core of the Satversme as a general legal principle in Latvia's constitutional system, which is said to be reflected by the declaration, adopted at the Saeima's sitting of 2 February 2012, "On the national importance of the Latvian language" and the position adopted by the Saeima in the legal proceedings before the Constitutional Court in case No. 2012-03-01. ${ }^{65}$ It must be noted that elsewhere in the European Union the protection of "inviolable articles", "unchangeable articles" or "Ewigkeitsklausel" ("eternity clauses") is resolved in the most diverse ways ${ }^{66}$; however, defining them in the constitution with

59 In its opinion, the Committee expressed the view that the Central Election Commission could prevent the possibility that an amendment to the Satversme, directed against the core of the Satversme, would be put for national referendum.

60 Augstākās tiesas Senāta Administratīvo lietu departamenta 30.04.2013. sprieduma lietā SKA-172/2013 motivu dal̦as 20. punkts [Decision of 30 March 2013 by the Senate of the Supreme Court of the Republic of Latvia in case No. SKA-172/2013]. Available: at.gov.lv/files/files/ [last viewed 13.09.2020].

61 Augstākās tiesas Administratīvo lietu departamenta 12.02.2014. sprieduma lietā Nr. A420577912 SA1/2014 motivu dal̦as 8. punkts [Decision of 12 February 2014 by the Supreme Court of the Republic of Latvia in case No. A420577912 SA-1/2014]. Available: at.gov.lv/files/files/ [last viewed 13.09.2020].

62 Augstākās tiesas Administratīvo lietu departamenta 28.03.2014. sprieduma lietā SA-3/2014 motīvu dalias 12. punkts [Decision of 28 March 2014 by the Supreme Court of the Republic of Latvia in case No. SA-3/2014]. Available: at.gov.lv/files/files/ [last viewed 13.09.2020].

63 Ibid.

64 Ekspertu komentāri Uzṇēmumu registra valsts notāres Lilitas Strodes 2013. gada 14. marta lēmumam Nr. 10-11/1850 [Expert Commentary to the Decision of the State Notary of the Enterprise Register Lilita Strode of 14 March 2013 No. 10-11/1850]. Jurista Vārds, No. 28, 23.04.2013, p. 28.

65 Meistere, D. Saeimas Juridiskā biroja atzinums ... [Opinion of the Saeima Legal Office ...], pp. 12-13.

66 Unconstitutional Constitutional Amendments. The Limits of Amendment Powers. Edited by Loughlin, M., McCormick, J. P., Walker, N. United Kingdom: Oxford University Press, 2017, pp. 23-26. 
more complicated procedure of amending them is characteristic. ${ }^{67}$ For example, in Italy ${ }^{68}$ and France, ${ }^{69}$ which also have complicated experience with changes and transformations in the constitutional status, this issue has been resolved in a rather simple way - by establishing in the constitution a prohibition to change the republican democratic form of government. Assessing the Latvian situation, one can say that for us the year of 2012 turned out to be fatal, when the decision had to be made in a referendum on the second official language in the so-called "language referendum. ${ }^{70}$ The political elite was noticeably bewildered: President Andris Bērziñ̌s boycotted the referendum demonstratively, thus indicating that ignoring the referendum ("disrupt the quorum") was the best civil solution, whereas the position parties of the Saeima, which also were Latvian parties, made a joint announcement, urging citizens to participate in the referendum ${ }^{71}$ and vote against Russian as the second official language... It seems that the ability of colleagues-lawyers to create an authoritative "concept of the core of the Satversme" deserves commendation.

Furthermore, it must be noted with respect to the protection of the basic articles of the Satversme, established in Article 77 of the Satversme, and the concept of the core of the Satversme, that an opinion exists that the primary aim of Article 77 of the Satversme is, nevertheless, "to remove" certain issues from the competence of the Saeima but not from that of the people, because the people have the right to decide on the foundations of their State ${ }^{72}$ and proposing some elements of the Satversme's core for the referendum should not be rejected. ${ }^{73}$ This suggests that, in the absence of clear normative regulation, the inviolability of the core of the Satversme strongly depends on the personal conviction of the responsible officials, judges. Practice is still in the stage of development, and the test of the protective elements for the concept of the Satversme's core (including the Preamble to the Satversme) is yet to come.

Concluding this insight into the core of the Satversme and the basic articles of the Satversme, it needs to be noted that, as stated above, they are only partially identical because twenty-eight articles of Chapter VIII of the Satversme

67 Latvijas Republikas Satversmes komentāri. V nodal̦a. Likumdošana [Comments of Satversme. Section V. Legislation], pp. 205, 262-265.

68 See Article 138 of the Italian Constitution. Available: https://www.constituteproject.org/constitution/ Italy_2012?lang=en [last viewed 04.09.2020].

69 See Article 89 of the French Constitution. Available: https://www.constituteproject.org/constitution/ France_2008?lang=en [last viewed 04.09.2020].

70 On 18 February 2012, national referendum was held in Latvia regarding adoption of the law "Amendments to the Satversme of the Republic of Latvia". The draft law envisaged amending Articles 4, 18, 21, 101 and 104 of the Satversme, including therein also provisions on the Russian language as the second official language, providing that the working languages of local governments were Latvian and Russian and that everyone had the right to receive information in Latvian and in Russian. The ballot paper of the referendum comprised the question "Are you for the adoption of the draft law "Amendments to the Satversme of the Republic of Latvia, which envisages grating the status of the second official language to the Russian language?"'. The possible answers were "In favour" and "Against". Available: https://www.cvk.lv/lv/tautas-nobalsosanas/par-grozijumiem-latvijas-republikassatversme-2012 [last viewed 04.09.2020].

71 Prezidents: referendums par valodu nebūs gada svarīgākais notikums [President: language referendum will not be the most important event of the year]. Available: https://www.tvnet.lv/4739059/prezidentsreferendums-par-valodu-nebus-gada-svarigakais-notikums [last viewed 04.09.2020].

72 Nikulceva, I. Satversmes 77. panta komentārs [Comment of Article 77 of the Satversme]. In: Latvijas Republikas Satversmes komentāri. V nodaļa. Likumdošana [Comments of Satversme. Section V. Legislation], p. 271.

73 Paparinskis, M. Piezimes par Satversmes preambulas projektu [Notes on the draft preamble to the Constitution]. Jurista Vārds, No. 43, 22.10.2013, p. 36. 
"Fundamental Rights", as well as seven paragraphs of the Preamble and the principle of the nation state revealed therein, are left outside the enumeration of Article 77. We can read in the opinion of the Constitutional Law Committee that "the scope of the inviolable part of the constitutional identity can be outlined only approximately", ${ }^{74}$ which resonates with the opinion of Juris Jelāgins, Justice of the Constitutional Court", that "not each amendment to the content of the core articles of the Satversme is such that demands approval thereof in a referendum." ${ }^{75}$ The principle of proportionality, which is an institutional principle and has joined the circle of the basic articles of the Satversme, in particular, points to this. ${ }^{76}$ In contrast to other fundamental principles of the aforementioned article, which belong to the Satversme's core and are, in Dišlers' words, "under the people's safeguard" (general, equal, direct and secret election), the principle of proportionality is a constitutional principle, which should not claim to be part of "the eternity clause". In this respect, to my mind, the Lithuanian constitution is worth mentioning, - its basic articles (Chapter 1 of the Lithuanian Constitution) also must be approved in a referendum; however, it does not comprise the model or the principles of election, as it is in Latvia $^{77}$. At the same time, as in an expanded constitution, a number of various symbols, institutions and regulations is listed in the basic articles, thus making their replacement difficult (for instance, flag, anthem, coat-of-arms, language, territorial integrity, the principles that "state institutions should serve the people", "the nation realises it supreme sovereign power either directly or via their democratically elected representatives"78, etc.). In the context of this article, it must be particularly highlighted that the basic articles or rather the basic principles of the Lithuanian constitution comprise also the referendum as the main way for deciding on the most important national issues - "the most significant issues concerning the life of the State and Nation shall be decided by referendum". ${ }^{79}$

\subsection{The Right of the Totality of Citizens to Decide on Amendments to the Satversme and Its Exercise in Practice}

Assuming that the basic law of any state is, essentially, the agreement by the people themselves on the form of the State power, principles of governance and institutions, the people should have the right to amend such an agreement the right to the constitutional power. This right should be genuine rather than such that cannot be exercised. The Latvian Constitutional Court has stated: the Satversme guarantees the exclusive right of the Latvian people to act on the fundamental

74 Konstitucionālās tiesību komisijas 17.09.2012. viedoklis par Latvijas valsts konstitucionālajiem pamatiem un neaizskaramo Satversmes kodolu [Opinion by the Commission of Constitutional Law from 17.09.2012 on the Constitutional Foundations of the State of Latvia and Inviolable Core of the Satversme]. Available: http://blogi.lu.lv/tzpi/files/2017/03/17092012_Viedoklis_2.pdf [last viewed 04.09.2020], p. 129.

75 Satversmes tiesas tiesneša Jura Jelāgina 2009. gada 21. aprīḷa atsevišḳās domas lietā Nr. 2008-35-01 [Separate thoughts of the Constitutional Court Judge Juris Jelāgins in case No. 2008-35-01 of 21 April 2009]. Available: https://juristavards.lv/doc/194927-satversmes-tiesas-tiesnesa-jura-jelaginaatseviskas-domas/ [last viewed 04.09.2020].

76 Supe, V. Satversmes 6. panta komentārs [Comment of Article 6 of the Satversme]. In: Latvijas Republikas Satversmes komentāri. II nodal̦a. Saeima [Comments of Satversme. Section II. Parliament]. Collective of authors, scientific ed. Prof. Balodis, R. Rīga: Latvijas Vēstnesis, 2020, p. 114.

77 See Article 148 of Lithuanian Constitution.

78 Ibid., Article 4.

79 Ibid., Article 9. 
norms of the Satversme, whereas the Saeima has only the power to review, which differs from the constitutional power of the Latvian people. ${ }^{80}$

As stated above, the Saeima has the right to amend the Satversme in the legislative procedure and the people (totality of citizens) - in the procedure of referendums.

Poet and member of the Constitutional Assembly Jānis Rainis has said that the referendum is one of fundamental rights of the people. ${ }^{81}$ In Latvia, the majority of referendums have not been successful. ${ }^{82}$ The total number of referendums in Latvia to date is eleven, of which four have been organised during the first period of independence (1923, 1927, 1931 and 1934), but the rest - in the second period of independence $(1998,1999,2003,2007$, two in 2008 and in 2011). In two of these referendums (2008 and 2012), electors voted for amendments to the Satversme, and on both occasions, viewing it from the legal perspective, these referendums were unsuccessful because one half of those with the right to vote did not vote in support of the amendments, as required by Article 79 of the Satversme. Only $42 \%$ of electors participated in the referendum of 2008, which meant that the amendments were not approved, whereas in 2012, although $71.13 \%$ of voters participated in the referendum, the majority voted against the amendments. It is important to note that only in two referendums out of the eleven in total (in 2003 and 2011), the people approved of the issue proposed for the referendum. Both these referendums were sufficiently exclusive cases: the referendum of 2003 on membership in the European Union had a massive, comprehensive state-supported campaign, nothing resembling it, in terms of financial support and extensiveness of scope, has happened in Latvia. To have a positive outcome, Satversme was amended, adding a new article to the Satversme, which significantly decreased the quorum of participation, whereas in the referendum of 2011, in which only $44.73 \%$ of electors participated, the people protested against the power, proven by the fact that a convincing majority of voters $(94.3 \%)$ supported the dissolution of the Saeima. ${ }^{83}$ It needs to be added that if the two aforementioned referendums had been referendums for amending the Satversme, they would have failed because the successful outcome was based on significantly lower algorithms for quorums compared to the case of amendments to the Satversme. ${ }^{84}$

Thus, if anyone now would want to organise a referendum in Latvia, in which the totality of citizens could exercise their constitutional rights and amend the Satversme, this organiser should be aware that 774337 electors should vote in

80 Judgment of 29 November 2007 by the Constitutional Court in case No. 2007-10-0102, para. 31.1.

81 Rainis, J. Vispārējās debates par Satversmes I dal̦u IV sesijas 5. sēdē, 1921. gada 28. septembrī stenogramma [Transcript of the $5^{\text {th }}$ sitting of the IV Session of the Constitutional Assembly 28.09.1921], p. 111.

82 Taube, C. Constitutionalism in Estonia, Latvia and Lithuania. A study in comparative constitutional law. [S. 1.]: Iustus Förlag AB, 2001, pp. 116-117.

83 Balodis, R., Kärkliņa, A., Danovskis, E. The Development of Constitutional and Administrative Law in Latvia after the Restoration of Independence. Journal of the University of Latvia. Law, No. 5, 2013, pp. 75-82.

84 For Latvia to join the European Union, at least a half of the number of electors who had participated in the previous Saeima election had to turn out, and the majority had to vote for the adoption of the draft law. This meant that if nearly $72 \%$ of all electors had participated in the election of the $7^{\text {th }}$ convocation of the Saeima, then the election would be legitimate if only $36 \%$ of all electors were to participate and only $18 \%$ vote in support of the proposition, whereas the Saeima may be dissolved in national referendum if more than a half of those electors, who participated in the referendum, were to vote for its dissolution. 
favour of the amendments to the Satversme. We arrive at this number by dividing 1548673 , which is the number of electors at the last election of the $13^{\text {th }}$ Saeima. ${ }^{85}$ If we take into account that $54.6 \%$ of electors participated in the last Saeima election, which is, accordingly, 844925 persons, it becomes clear why experts deem the possibility of amending the Satversme in a referendum as being only theoretical. ${ }^{86}$ As generally known, considerably more persons participate in the parliamentary election than in a referendum. Exactly because of this, despite the opinion of many ${ }^{87}$, the Preamble to the Satversme was not proposed for a referendum but was adopted by the Saeima. Most probably, it would not have been adopted in a referendum because, despite the group of enthusiasts, there was no lack of sceptics also among Latvians ${ }^{88}$, and to exceed the quorum set in Article 79 of the Satversme, the totality of citizens should be really interested in the issue, which, as known, was not so even in the language referendum, in which less than $50 \%$ of the electors participated. Therefore, it is natural that none of the referendums aimed at amending any of the norms enumerated in Article 77 of the Satversme has legally occurred due to quorum. None of the norms of the Satversme has been adopted in a referendum. Perhaps it is pertinent to quote the prophetic words by Kārlis Dzelzìtis, a member of the Constitutional Assembly, said at the Assembly's siting on 15 February 1922 directly before the final reading for the adoption of the Satversme: "[...] scholars and, likewise, voters, reading this Satversme, will just smirk at that legislative institution, which, as it were, had wanted to grant some democratic rights to the people but actually stretched out an empty hand to them [..] because the practice will prove that the right to referendum actually cannot be exercised." ${ }^{89}$ Dzelzitis did not utter these words with respect to amending the Satversme in a referendum; however, this statement is uncontestably applicable both to the exercise of the people's right to a referendum and the people's right to amend the constitution of their State.

\subsection{On the Constitutional Quorum Set for Amending the Satversme in a Referendum}

With respect to a referendum, in which the Satversme could be amended, the Constitutional Assembly from the very beginning set the highest of the constitutional quorums, which, accordingly, is defined in the first part of Article 79. This quorum, just like other constitutional quorums, has a two-fold aim because it serves (1) as a restriction (barrier, obstacle) to ill-considered amendments to the Satversme;

85 Moreover, it should be taken into account that 134806 of the electors have registered their place of residence abroad, and the practice shows that their link with Latvia is not too strong because only nearly $24 \%$ voted at the election of the $13^{\text {th }}$ convocation of the Saeima (Latvijas Republikas Centrālās vēlēšanu komisijas oficiāls izdevums "13. Saeimas vēlēšanas 2018. gada 6. oktobrī. Vēlēšanu rezultāti" [The Official Publication by the Central Election Commission of the Republic of Latvia. Election of the $13^{\text {th }}$ Convocation of the Saeima on 6 October 2018. Election Results]. Riga: Latvijas Republikas Centrālā vēlēšanu komisija, 2018, p. 4. Available: https://www.cvk.lv/upload_file/2018/13\%20 Saeimas\%20velesanu\%20rezultati\%20A4\%20_ML.pdf [last viewed 04.09.2020]).

86 Nikuļceva, I. Satversmes 77. panta komentārs [Comment of Article 77 of the Satversme], p. 269.

87 Jurista Vārda lasitāju aptaujas rezultāti [The results of a survey of readers]. Jurista Värds, No. 43, 22.10.2013, p. 7 .

88 Ibid., pp. 13-18.

89 Satversmes sapulces sēžu stenogrammas, for example, Satversmes I daļas lasī̌̌ana pa pantiem. V sesijas 14. sēdes (1922. gada 15. februārī) stenogramma [Transcript of the $14^{\text {th }}$ sitting of the V Session of the Constitutional Assembly 15.02.1922]. In: Latvijas Satversmes sapulces stenogrammu izvilkums (1920-1922) [Transcript of the Latvian Constitution Asambley Meeting (1920-1922)], p. 850. 
(2) to establish the "correct expression" 90 and "unmistakable will"91 of the people, moreover, the requirement follows from the rational basis of the public law institutions. ${ }^{92}$ It must be proven by "full quorum". ${ }^{93}$ Thus, the quorum plays an important role and its expedience is rooted in the very substance of the people's government because it does not allow a small part of the people to impose upon the majority an order, which, possibly, is dangerous and may possibly jeopardise the constitutional stability of the State. At the same time, if the quorum has been set too high and is unattainable, it may turn into a barrier for any collective decision, mothballing the constitutional development. The Latvian Saeima, at the very last stage of the first period of parliamentarianism, reached the conclusion that one of its constitutional quorums was excessively high. In 1933, the first amendments to the Satversme were proposed and adopted by the Saeima, which was done after four referendums had failed because of the high required quorum. The Saeima, the Central Election Commission and several presidents ${ }^{94}$ were involved in the discussion, which lasted for years. The discussion had placed the political elite of the first independence period in a very awkward situation, so that the Saeima had to liberalise the procedure of referendum.

When examining amendments to Article 74 and Article 79 of the Satversme, members of the parliament engaged in long discussions, speakers were numerous, the usefulness and scope of quorums were extensively discussed. In view of the fact that the discussions focused on Article 74 of the Satversme, which, prior to the Satversme amendments of 1933, defined the participation quorum for a referendum - "a half of all electors", which is still found in Article 79 with respect to amendments to the Satversme, this discussion is still relevant today. I shall quote the most vivid statements made by the speakers:

[..] the quorum is needed not to make a referendum ridiculous [..."; the quorum "may influence or adjust the parliament's legislative practice and erroneous is the illusion if one wants to perceive this matter as if the referendum could stand side by side or replace the legislation by the house of the people's representatives [..]"; ${ }^{95}$ "[..] While our Saeima has isolated and reinforced itself so much that the sovereign people do not reach it anywhere. [..] This is why you, gentlemen, are afraid of the law on referendum in such a form as demanded by the majority of our people. [..]"; "[..] if we look at the referendums that have taken place, we see that the people have never had the sovereign power in the State of Latvia. The sovereign power has had the right

90 Dišlers, K. Ievads Latvijas valststiesību zinātnē [Introduction to Latvian State Law Science], p. 148.

91 Latvijas Republikas IV Saeimas V sesijas 4. sēde 1933. gada 10. februārī [Transcript of the $4^{\text {th }}$ sitting of the V Session of the Latvian IV Saeima [Parliament] 10.02.1933], pp. 149-150.

92 Pleps, J. Satversmes iztulkošana [Translating the Constitution]. Rīga: Latvijas Vēstnesis, 2012, p. 197.

93 Latvijas Republikas IV Saeimas V sesijas 4. sēde 1933. gada 10. februārī [Transcript of the $4^{\text {th }}$ sitting of the V Session of the Latvian IV Saeima [Parliament] 10.02.1933], pp. 149-150.

94 See more in Latvijas Republikas Satversmes grozijumi. Latvijas Republikas Satversmes grozijums Nr. 1 [Amendments to the Constitution of the Republic of Latvia. Amendment 1 to the Constitution of the Republic of Latvia]. In: Latvijas Republikas Satversmes komentāri. V nodaļa. Likumdošana [Comments of Satversme [Constitution]. Section V. Legislation], pp. 220-221.

95 Latvijas Republikas IV Saeimas V sesijas 3. sēdes (1933. gada 7. februārī) stenogramma [Transcript of the $3^{\text {th }}$ sitting of the V Session of the Latvian IV Saeima [Parliament] 07.02.1933]. In: Latvijas Republikas IV Saeimas V sesija [V Session of the Latvian IV Saeima [Parliament], p. 110.

96 Ibid., p. 113. 
but has never had the possibility to express its opinion on those draft laws that had been put for the people's vote [..].

Feelikss Cielēns, who reported on the draft law of the Satversme, noted that it could well be a case in Latvia that "[..] a rather small group could propose a draft law that it deemed important but the largest part of the people could consider it irrelevant, and therefore they would not participate in the referendum at all [..]" ${ }^{\prime 97}$

Cielens, as the rapporteur on the draft law, expressed the concern that if the quorum would be even lower [he spoke about the quorum for a draft law, which was supported, - "the number of electors is at least half of the number of electors who participated in the previous Saeima election" ${ }^{98}$ it might happen that a small number of people started issuing laws and this would be contrary to the laws issued by the parliament. ${ }^{99}$ Cielens expressed the conviction that only an adjustment of the parliament's will could be obtained in a referendum. ${ }^{100}$ The politician saw any further reduction of the quorum as a genuine threat to the party of social democrats because the rightists could achieve, via a referendum, a president elected by the people, with greater powers. ${ }^{101}$ It must be added regarding these debates that also that the Saeima was urged to not stop at what had been achieved but review also the quorum for amending the Satversme. Member of the Saeima Andrejs Zakis proposed both at the sitting of the Public Law Committee and the Saeima that the algorithm of a decreased quorum should also be applied to amendments to the Satversme, offering the following wording of Article 79: "Amendments to the Satversme, put for the national referendum, shall be adopted if more than a half of all voters approve of them". The Saeima dismissed this proposal without lengthy discussions. It was supported only by radical Pēteris Leikarts, who insisted that the quorum should be abolished altogether. In the decisive voting by the Saeima, the legislative initiatives by the deputies from both minor parties (New Famer's Union, Union of Peace, Order and Production) gained only few votes. ${ }^{102}$ The Saeima lowered the quorum requirements for adopting laws ${ }^{103}$ and revoking them in

97 Latvijas Republikas IV Saeimas V sesijas 3. sēdes (1933. gada 7. februārī) stenogramma [Transcript of the $3^{\text {th }}$ sitting of the V Session of the Latvian IV Saeima [Parliament] 07.02.1933]. In: Latvijas Republikas IV Saeimas V sesija [V Session of the Latvian IV Saeima [Parliament], p. 126.

98 The initial wording of Article 74 of the Satversme, prior to the amendments of 1933: "A law adoped in the Saeima and suspended in the procedure of Article seventy-two may be revoked in national referendum if al least half of the electorate has participated in the referendum." The wording of Article 74 of the Satversme following the amendments: "A law adoped in the Saeima and suspended in the procedure of Article seventy-two shall be revoked in national referendum of the number of electors is at least half of the number electors who participated in the previous Saeima election and the majority voted for revoking of the law." Initial wording of Article 79 of the Satversme prior to the amendments of 1933: "Amendments to the Satversme put for national referendum shall be adopted if at least half of electors approve of them." (The current effective wording of Article 79 of the Satversme can be found in the introductory part of this article).

99 Ibid.

${ }^{100}$ Briede, J. Satversmes 79. panta komentārs [Comment of Article 79 of the Satversme]. In: Latvijas Republikas Satversmes komentāri. V nodal̦a. Likumdošana [Comments of Satversme [Constitution]. Section V. Legislation], pp. 295-296.

${ }^{101}$ Latvijas Republikas IV Saeimas V sesijas 4. sēde 1933. gada 10. februāri [Transcript of the $4^{\text {th }}$ sitting of the V Session of the Latvian IV Saeima [Parliament] 10.02.1933], pp. 113, 116, 159-162, 187-168.

102 Ibid., pp. 113, 116, 159-162, 187-188.

103 The Public Law Committee (the Committee responsible for the advancement of amendments) decidied, by majority vote, to decrease the quorum and, as the result, the Saeima amended the Satversme in 1933, envisaging that in the national referendums on draft laws "the number of electors 
a referendum, ${ }^{104}$ but the people did not manage to use these easements in the prewar parliamentarianism. Only a year after these amendments to the Satversme, on 15 May 1934, members of the Saeima were dispersed, the Saeima was liquidated but the Satversme itself, including the amended provisions, was suspended ${ }^{105}$ "until implementing a new reform of the Satversme". ${ }^{106}$ The fact that a referendum on amendments to the Satversme has never happened in the forty years of the Satversme's existence suggests that, in Latvia, the people's right to amend the Satversme was formal by nature from the very moment of its adoption, not intended for practical use. Quoting Dzelzitis, "an empty hand" hand been stretched out to the people. Looking into the transcripts of the Constitutional Assembly, one has to conclude that already in developing the procedure for amending the Satversme, including into it the quorum of "absolute majority of vote", the constitutional legislator had clearly intended to significantly reinforce the foundations of the State and make the change of the political system very difficult. This mentality is revealed in Kārlis Dišlers' reflections on amending the Satversme in the Herald of the Ministry of Justice in 1921, thus, a year before the Satversme was approved. ${ }^{107}$ In examining the mandatory constitutional referendum, established in Article 77 of the Satversme, Dišlers writes that, in his opinion, any amendment to the Satversme should be put for a referendum. Any?! The total lack of discussions at the Constitutional Assembly ${ }^{108}$ and the Committee for Drafting the Satversme, ${ }^{109}$ as well as the joint sittings ${ }^{110}$ testifies to admirable consensus of various political forces with respect to the procedure for amending the constitution and the elements thereof - the restrictions. Members of the Constitutional Assembly discussed the model for electing the President ${ }^{111}$ intensely and at length, while, actually, the political forces covering the whole spectrum, both rightist and centrist and also leftist had no wish to experiment with the manifestations of the people's will taking

shall be at least half of the number of electors who participated in the last Saeima election, with the majority of electors voting in favour".

${ }^{104}$ Kusiňš, G. Satversme un Latvijas konstitucionālo institūciju izveidošana [Constitution and Establishment of the consitutional institutions]. In: Pamattiesibas. Pilsoniba. Latvijas Valsts tiesību avoti. Valsts dibināšana - neatkarības atjaunošana. Dokumenti un komentāri [Fundamental rights. Nationality. Sources of Latvian State law. Establishment of the State - renewal of independence. Documents and commentary]. Rīga: Tiesu namu aǵentūra, 2015, p. 62.

105 Valdības deklarācijas [Government declaration]. Valdības Vēstnesis, No. 10, 19.05.1934.

106 The people lost even the formal possibility to go to the ballot-boxes to express their opinion - the people only had "the right" to cheer for the leader Kärlis Ulmanis and create floral "arcs of honour" for him. Ulmanis' authoritarianism did not allow any plebiscite. Professor Kārlis Dišlers, apparently, to keep is position and salary during authoritarianism, attempted to legally justify it and interpreted the non-resistance to the coup of 15 May 1934 as "approval and support", which had not been put into "a legal form" but should be deemed to be sufficient (Dišlers, K. Negotiorium gestio publisko tiesību novadā [Negotiorium gestio in the Area of Public Law]. Tieslietu Ministrijas Vēstnesis, 1935. gads, p. 42).

107 Dišlers, K. Dažas piezīmes pie Latvijas Republikas Satversmes projekta (tieša likumdošana un Valsts prezidents) [Some remarks on the draft Constitution of the Republic of Latvia (direct legislation and President of Latvia)]. Tieslietu Ministrijas Vēstnesis, 1921, No 4/6, pp. 142-143.

108 Briede, J. Satversmes 79. panta komentārs [Comment of Article 79 of the Satversme], p. 295.

109 See Satversmes izstrādes komisijas 1921. gada 6. aprīịa sēdes protokols [Minutes of the Constitutional Assembly Constitutional Commision Meeting 06.04.1921]. Unpublished material.

110 See, IV sesijas 20. sēdes (1922. gada 9. novembrī) stenogramma [Transcript of the $20^{\text {th }}$ sitting of the IV Session of the Constitutional Assembly 9.11.1922]. In: Latvijas Satversmes sapulces stenogrammu izvilkums (1920-1922) Transcripts of Latvian Constitution Asambley Meeting], pp. 466, 850.

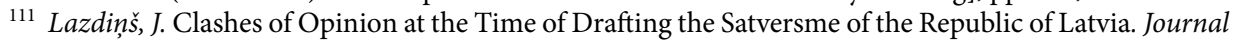
of the University of Latvia. Law, No. 10, 2017, pp. 95-98. 
the form of amendments to the Satversme. Neither have serious discussions about the high quorum in the first part of Article 79 occurred today, although nobody doubts that the high quorum is "not suitable for the needs of life". The best proof of it are the amendments to the Satversme of 2003, ${ }^{112}$ when especially for joining the European Union ${ }^{113}$ the high quorum was lowered for referendums with respect to the European Union. This leads to the conclusion that the high quorum for amendments to the Satversme, in tandem with the outdated institution of the people's vote of the reinstated Satversme of 15 February $1922^{114}$, staunchly protects the Satversme from any impact by the people.

\section{Improving the Procedure for Amending the Satversme}

\subsection{Reflecting on the Statements Made by Jānis Rainis, the Member of the Constitutional Assembly, About Burgeois Fear of the National Referendums}

On 20 July 2012, the Central Election Commission organised the conference "The Arithmetic of the People's Will: Elections and Referendums in Latvia", in which the organisers expressed the most correct opinion that a referendum was a good way for the people to express their opinion and participate in the political process. ${ }^{115}$ This conclusion, expressed in the distant year of 2012, is referred to for a good reason, because this was the decisive year both for referendums and the drafting of the concept of the Satversme's core. It was the referendum of 2012 on the second official language - the Russian language - that made the Saeima decide on such amendments to the Law on National Referendums, Initiation of Laws and European Citizen's Initiative, ${ }^{116}$ which, at the end of the day, entirely suspended national referendums. The statements made by politicians that the concerns that the amendments would make the organisation of referendums impossible was only scaring the people ${ }^{117}$ turned out to have been only excuses. The procedure became so unwieldy ${ }^{118}$ that it stopped functioning altogether. Aivars Ozoliņš, the well-known publicist, assessed it as follows in the magazine "Ir":

${ }^{112}$ Nikuḷceva, I. Tiešā demokrātija Eiropā [Direct democracy in Europe]. Jurista Vārds, No. 169, 26.10.2010.

${ }^{113}$ Saeima lems par Satversmes grozišanu sakarā ar Eiropas Savienību [Saeima will decide on amending the Constitution in connection with the European Union]. Jurista Värds, No. 7, 18.02.2003.

${ }^{114}$ Nikuḷceva, I. Fakultatīvā tautas nobalsošana Latvijā un Eiropā [Optional National Referendums in Latvia and Europe]. Juridiskās zinātnes aktuālās problēmas [Current challenges of legal science]. Rīga: Zvaigzne ABC, 2012, p. 411.

115 Platace, L. Vēlētāju tiesības ierosināt referendumus pārmainu priekšā [Voters' right to propose referendums to face changes]. Available: https://lvportals.lv/norises/250193-veletaju-tiesibas-ierosinatreferendumus-parmainu-prieksa-2012 [last viewed 10.09.2020].

${ }^{116}$ Par tautas nobalsošanu, likumu ierosināšanu un Eiropas pilsoṇu iniciatīvu: LR likums [Law on National Referendums, Initiation of Laws and European Citizens' Initiative: Law of the Republic of Latvia]. Latvijas Vēstnesis, No. 47(178), 20.04.1994.

117 Čepāne, I. Latvija ir referendumu paradīze [Latvia is a Paradise for Referendums]. Jurista Värds, No. 34, 21.08.2012.

118 The draft law, as described by Gunārs Kütris, introduced revolutionary changes, brought by the amendments of 8 November 2012, pursuant to the new procedure the draft law, first of all, must be registered with CEC. Secondly, the initiators of the draft law must ensure themselves that the signatures of at least one-tenth of electors are collected. This means that the State supports neither the organising of the process of collecting signatures nor finances it. Likewise, Kütris expresses suspicion that the problem is vested not only in the major restrictions established for the national referendums but also in the possibility to manipulate. I.e., if the state power genuinely does not want a national referendum, it can set an inconvenient date of the referendum and fail it, for example, setting a date 
Politicians' presumption to protect the State from its citizens by restricting their rights is a bad style of behaviour. [..] The authors of the draft law are dealing with a non-existent problem and attempting to prevent the possibility to hold the referendums altogether rather than preclude some undesirable consequences of them. ${ }^{119}$

Not only publicists ${ }^{120}$ but also scholars of law who have studied the regulation on referendums have concluded that it is almost impossible for the people to initiate referendums. Thus, for instance, Annija Kārkliņa recognises ${ }^{121}$ that the procedure of a national referendum in Latvia more or less functioned until the moment when it was prohibited by the amendments of $2012^{122}$ to the law on National Referendums, Initiation of Laws and European Citizen's Initiative. Gunārs Kūtris, the former President of the Constitutional Court, has also sounded alarm, stating that the legal procedure should be real not only declarative, giving the possibility to the people to express their will in a national referendum. ${ }^{123}$ Inese Nikulceva is of a similar opinion, believing that the collection of electors' signatures electronically should be made easier and notarial certification of the electors' signatures should not be required. ${ }^{124}$

Examining the approach of the current political elite towards referendums, one has to return to the origins of the establishment of the State, when there were different opinions on creating the Constitutional Assembly. The People's Council in the Platform of 17 November $1918^{125}$ primarily advanced convening the Constitutional Assembly in the form of general election, whereas Andrievs Niedra, the creator of an alternative order of the State, had no intentions to organise election whatsoever because he planned the constitution of the Constitutional Assembly from curias or classes. ${ }^{126}$ Niedra was afraid that general election might result in communists coming into power. It is ridiculous but also the Latvian Bolsheviks were afraid of the people, therefore instead of general election were planning class election, where the right to vote would be granted only to the class of proletariat. ${ }^{127}$ Finally, the election is held on 17-18 April 1920, and the State takes the form of a democratic republic; however, the initial fear from the people's voice never

when people have no time or wish to go to the electoral districts (see Kütris, G. Referendumi jeb tautas nobalsošanas: cik tas ir reāli [Referendums or the people's vote: How real is it]. Jurista Vārds, No. 42, 28.10.2014, p. 22.

119 Ozoliņ̌s, A. Vienotības piga [Vienotība cocking a snook]. Ir, 26.07.-01.08.2012, p. 6.

${ }^{120}$ Ibid.

${ }^{121}$ Kärklina, A. Requirements to be Set for Voters' Legislative Initiatives in the Republic of Latvia: Legal Regulation, Practice, and Recent Findings of Judicature. Journal of the University of Latvia. Law, No. 10, 2017, pp. 154-155.

${ }^{122}$ Grozijumi likumā "Par tautas nobalsošanu, likumu ierosināšanu un Eiropas pilsoṇu iniciatīvu": LR likums [Amendments to "Law on National Referendums, Initiation of Laws and European Citizens' Initiative": Law of the Republic of Latvia] (08.11.2012). Latvijas Vēstnesis, No. 186(4789), 27.11.2012.

${ }^{123}$ Kütris, G. Referendumi ... [Referendums ...].

124 Nikuļceva, I. Tautas nobalsošana un vēlētāju likumdošanas iniciatīva. Promocijas darbs [Doctoral thesis "National Referendum and Voters' Legislative Initiative"]. Rìga: Latvijas Universitāte, 2012, p. 206. Available: https://dspace.lu.lv/dspace/bitstream/handle/7/5120/22881-Inese_Nikulceva_2013. pdf? sequence $=1$ [last viewed 04.09.2020].

${ }^{125}$ Latvijas Tautas padomes politiskā platforma [Political platform of the People's Council]. Pagaidu Valdības Vēstnesis, No. 1, 14.12.1918.

${ }^{126}$ Balodis, R., Lazdiñš, J. Satversmes vēsturiskā attīstïba [Historical development of the Latvian Constitution]. In: Latvijas Republikas Satversmes komentāri. Ievads. I nodaļa. Vispārējie noteikumi [Comments of Satversme [Constitution]. Preamble. Section I. General rules], pp. 54-55.

127 Šiliņ̌š, J. Padomju Latvija 1918-1919 [Soviet Latvia 1918-1919]. Rīga: Vēstures izpētes un popularizēšanas biedrïba, 2013, p. 93. 
disappeared but, on the contrary, became characteristic of the Latvian political system. Latvian poet Jānis Rainis has pointed to it at the Constitutional Assembly, stating, in one of his rare addresses, the following:

[..] It is, however, in the interests of the people to upkeep this State, and by its vote the people will upkeep this State and make it stronger. When they have this right, they will feel even a stronger bond with the State than now [..]. I regard this right to vote as harmless, even from the bourgeois standpoint. [..] the introduction of referendums [..] is a step towards educating the people politically [..]. ${ }^{128}$

In Rainis' opinion, the procedure established in the Satversme restricts the national referendum to the extent that a referendum is no longer possible, there is no vote by the people,

[..] because such might happen with us only on the rarest occasions of happiness. But this is not a matter of happiness but of law. The bourgeois is afraid of national referendums. This fear seems to be unfounded. ${ }^{129}$

Rainis pointed out to the Constitutional Assembly that the consequences of placing such restrictions on holding of referendums would be the lack of political education among the people, which, in turn, would lead to the lack democratism. ${ }^{130}$ The forecasts made by the outstanding poet are proven by the people's attitude towards the authoritarian coup of 15 May 1934. The people did not rush to defend the constitutional order but perceived authoritarianism with hope and, even, understanding. Rainis' statements come to mind also when examining the discussions among the members of the last pre-war convocation of the Saeima on the respective issues. The reciprocal hatred and lack of trust among the political groups are obvious, only fear from the changing opinion of the people unites all groups. ${ }^{131}$ Following the restoration of Latvia's independence, the dislike towards national referendums was inherited and turned into a typical element of the Latvian parliamentary system. Although the institution of national referendums is called a strong instrument of the political fight ${ }^{132}$, the experience of using it in Latvia is very poor, the complex organisational procedures and high quorum are validly blamed for it.

${ }^{128}$ Rainis, J. Vispārējās debates par Satversmes I daļu IV sesijas 5. sēdē 1921. gada 28. septembrī stenogramma [Transcript of the $5^{\text {th }}$ sitting of the IV Session of the Constitutional Assembly 28.09.1921], p. 112 .

129 Ibid., p. 111.

130 Ibid., p. 112.

131 The speeches made by the deputies reveal not only the reciprocal hatred of the various political branches but also fear that if it were easier to hold national referendums the elector could significantly amend the Satversme, thus destroying the State. All were afraid of the communists, but social democrats - of the rightist forces. In the sitting on the quorums, when active debates evolved, Fricis Bergs openly expressed the dislike of the communists, represented in the parliament, for the parliamentary system, saying that it was beyond remedy, openly praised the proletarian dictatorship of Moscow, which was said to be the genuine dictatorship of workers. In atmosphere like this, the cautious approach taken by the people's representatives towards liberalisation of referendums is quite understandable (see Latvijas Republikas IV Saeimas V sesijas 3. sēde 1933. gada 7. februārī [Transcript of the $3^{\text {th }}$ sitting of the V Session of the Latvian IV Saeima [Parliament] 07.02.1933], pp. 130-132; Latvijas Republikas IV Saeimas V sesijas 10. sēdes (1933. gada 10. martā) stenogramma [Transcript of the $10^{\text {th }}$ sitting of the V Session of the Latvian IV Saeima [Parliament] 10.03.1933]. In: Latvijas Republikas IV Saeimas V sesija. 1933. gads, pp. 374-382).

132 Pastars, E. Referendumu nedienas [Troubles with Referendums]. Diena, 03.08.2002. 


\subsection{Proposals for Improving the Procedure for Amending the Satversme}

Author of the first commentaries to the Satversme Kārlis Vanags ${ }^{133}$ wrote that the Satversme was something more than just a statute on the organisation of the State, it was the manifestations of the will of the people's majority regarding the type and form of its political expression. If these are not just mere beautiful words than the nation should be given a genuine and not solely a declarative opportunity to amend its Satversme. Without forgetting the national security and constitutional stability, the procedure for amending the basic articles of the Satversme should be separated from the procedure for amending other articles of the Satversme, which requires two types of quorums. The first one would be the existing "half of all electors" (the first part of Article 79 of the Satversme), it would apply to amending the basic articles of the Satversme, whereas the second quorum, which currently applies only to membership in the European Union, i.e., "the number of electors is half of the number of electors who participated in the last Saeima election" (the first part of Article 79 of the Satversme), could apply to the norms not enumerated in Article 77 of the Satversme. The possible wording: ${ }^{134}$

79. An amendment to the Satversme put for national referendum in the cases provided for in Article 77 shall be adopted if at least half of electorate approves of it. An amendment to the Satversme as well as a draft law, decision on Latvia's membership in the European Union or substantial changes in the terms regarding such membership shall be adopted if the number of electors is at least half of the electors who participated in the last Saeima election and if the majority voted for the adoption of the draft law, Latvia's membership in the European Union or significant changes in terms regarding such membership.

New second part could be added to Article 65 of the Satversme, providing that "amendments to the Satversme may be submitted to the Saeima by the President, the Committees of the Saeima, not ten members of the Saeima." This step would, however, separate the ordinary legislation from the Satversme, providing that a small faction of the Saeima would have to cooperate with the other factions in order to initiate amendments to the Satversme, and would not be a matter for the government. I also believe that an interval should be defined (at least three months) for the three readings established in Article 76, likewise, perhaps prohibition to amend the Satversme six months prior to the election should be established. It could be discussed whether this provision should be included in the Satversme or the Rules of Procedure of the Saeima.

In my opinion, the Saeima should consider pro et contra and either conclude that the referendum for adopting a decision has exhausted its possibilities and give up this expensive, archaic tradition ${ }^{135}$ or make the right to referendum operational. Why should the Saeima do it? The reason is the need for greater involvement of the people in the national politics. Approximately two-thirds (66\%) of the surveyed inhabitants do not trust the Latvian parliament, whereas the absolute majority $(82 \%)$

${ }^{133}$ Vanags, K. Latvijas valsts Satversme [The Constitution of the State of Latvia]. Valka: L. Rumaka apgāds, 1948, pp. 4-5.

134 Of course, amendments to Article 77 of the Satversme could be as logical, including in them the first sentence of the draft referred to above, leaving only the rest in the wording of Article 79; however, as stated in the article, it cannot be implemented in practice.

135 Timofejevs, P. Referendumi un demokrātija [Referendums and democracy]. Diena, 13.09.2003. 
does not trust the political parties ${ }^{136}$, and these indicators have retained similar proportions throughout years. ${ }^{137}$ Voters start losing interest also in the local government election, which is proven by the extraordinary election in the capital of Latvia Riga in 2020 , when only $40.6 \%$ of the inhabitants turned out to vote. ${ }^{138}$ This means that the Latvian citizens have a very limited belief in their own ability to change anything by means of election. It is not surprising that inhabitants are not satisfied with the election system. ${ }^{139}$ One of the main problems of the Latvian democracy is the distrust of the Latvian people in their own elected representatives or a divide between the people and the ruling elite. ${ }^{140}$ This divide can be decreased only by greater involvement of the people in decisions of national importance. That would only reinforce our democracy and, quoting Rainis, would educate the people politically (it is worth noting here that historians link the failure of parliamentary democracy of 1934 with the absence of responsible political culture and the inability of the Latvian political elite to communicate with the people). ${ }^{141}$ The right to referendum would increase the people's self-confidence. The first post-war President of Latvia Guntis Ulmanis has put this very aptly - referendums, apart from everything bad, have their positive moment: the people get a chance to draw a second breath and regain the sense of affiliation with the State. ${ }^{142}$ It must be added that this politician, although already in retirement, sadly concluded that the parliament continued to have the lowest rating for a long period and that this mechanism needed

136 2018. Autumn. Public opinion in the European Union Standard Eurobarometer 90. Available: file://C:/Users/User/AppData/Local/Temp/eb_90_data_annex_en.pdf https://ec.europa.eu/malta/ sites/default/files/st90-report.pdf [last viewed 04.09.2020].

${ }^{137}$ Latvia's inhabitants elect directly only the members of two institutions of public administration members of the Saeima and of the local governments. Participation in elections is not only the citizens' constitutional duty but also the main indicator of their political activity, just as the election results reveal the people's political sentiment and maturity. Election results, depending on the political perspective, may be satisfactory or not; however, the constantly decreasing citizens' activity in elections proves that a significant part of the people distance themselves from the public administration. The political elite gets more distant from the people with each election. A vivid example is the last election held in the summer of 2020 in the capital of Latvia Riga, when the majority of electors chose to stay at home. The same analogy is seen in the Saeima election, where in the last election of the $13^{\text {th }}$ convocation of the Saeima only $54.6 \%$ (844 925) of electors participated, which is significantly less than in the previous elections (e.g., election of the $8^{\text {th }}$ convocation of the Saeima, with the participation of $71.51 \%$ (997 754) of electors, but the last pre-war election of the $4^{\text {th }}$ convocation of the Saeima saw the participation of $80 \%$ of electors (974 822). Of course, also sociological surveys (for example, Eurobarometer survey held in 2018) show that only $19 \%$ trust the Latvian Saeima, i.e., less than one-fifth of the society...

${ }^{138}$ Only $40.6 \%$ of electors participated in the Riga City Council election, which is the lowest electorsactivity at least since 1997. No data can be found on the homepage of the Central Election Commission regarding the electors' activity in the local government election in Riga of 1994.

${ }^{139}$ Sabiedrỉbas apmierinātỉba ar pašreizējo vēlēšanu sistēmu varētu būt samazinājusies [Public satisfaction with the current electoral system could have decreased]. LETA. Available: https://www.apollo. lv/5299562/sabiedribas-apmierinatiba-ar-pasreizejo-velesanu-sistemu-varetu-but-samazinajusies [last viewed 04.09.2020].

140 Levits, E. Demokrātiskā valsts iekārta, brīvas vēlēšanas un parlamentārā demokrātija [Democratic State Administration, free elections and parliamentary democracy]. In: Parlamentārā izmeklēšana Latvijas Republikā. 1. parlaments. Parlamentārā kontrole [Parliamentary investigations in the Republic of Latvia 1. Parliament]. Scientific editor Prof. Balodis, R. Rīga: Latvijas Vēstnesis, 2016, p. 21.

141 Bleiere, D., Butulis, I., Feldmanis, I., Stranga, A., Zunda, A. Latvijas vēsture. 20. gadsimts [History of Latvia. $20^{\text {th }}$ century]. Riga: Jumava, 2005, p. 250.

142 Udris, J. Gunta Ulmaṇa vertikāle [ Guntis Ulmanis' Vertical]. Rīga: Jumava, 2009, p. 206. 
some improvements. ${ }^{143}$ Although this is an entirely different topic, there is one correlation - the people's trust in democratic institutions, which is disastrously decreasing in Latvia.

\section{Summary}

1. Providing an answer to the objective set in the beginning in the article, it can be concluded that the basic restrictions to amending the Satversme, which are included in Article 76 of the Satversme, are well elaborated and tested in practice, as opposed to the procedure for the mandatory constitutional referendum. The people's right to express their assessment of the Satversme is limited and practically impossible to exercise in Latvia.

2. The procedure for amending the Latvian constitution should be separated from the general legislation, restricting the circle of applicants and establishing a time interval between readings. A restriction on the approval of amendments to the Satversme by the Saeima during the last months of its term should be considered.

3. The participation quorum, defined in the first part of Article 79 of the Satversme, for amending the Satversme in national referendum ("half of the electorate"') should be applied to the basic articles of the Satversme, which are enumerated in Article 77 of the Satversme, i.e., Articles 1, 2, 3, 4, 6 and 77, but with respect to amendments to other articles of the Satversme, a lower participation quorum should be introduced, which would be "the number of electors is the half of the electors in the last Saeima election", which could be achieved by amending Article 79 of the Satversme.

4. The Central Election Commission together with the Analytical Service of the Saeima should review the experience with national referendums thus far and, following consultations with legal experts, should submit to the Saeima an opinion on the required improvements with respect to liberalisation of the regulation on national referendums.

\section{Sources}

\section{Bibliography}

1. Aizritējusi konference par Satversmes preambulas paplašināšanas projektu [A conference on the draft extension of the preamble to the Constitution has elapsed]. Jurista Värds, No. 45, 05.11.2013.

2. Balodis, $R$. The Constitution of Latvia. Rechtspolitisches Forum Legal Policy Forum Institut für Rechtspolitik an der Universität Trier, No. 26, 2004.

3. Balodis, R. Latvia. In: Encyclopedia of World Constitutions. Vol. II. Ed. Robbers, G. U.S. Facts on File, 2007.

4. Balodis, R., Kärklina, A., Danovskis, E. The Development of Constitutional and Administrative Law in Latvia after the Restoration of Independence. Journal of the University of Latvia. Law, No. $5,2013$.

5. Bleiere, D., Butulis, I., Feldmanis, I., Stranga, A., Zunda, A. Latvijas vēsture. 20. gadsimts [History of Latvia $20^{\text {th }}$ century]. Rìga: Jumava, 2005.

6. Čepāne, I. Latvija ir referendumu paradīze [Latvia is a Paradise for Referendums]. Jurista Vārds, No. 34, 21.08.2012.

7. Dišlers, K. Dažas piezīmes pie Latvijas Republikas Satversmes projekta (tieša likumdošana un Valsts prezidents) [Some remarks on the draft Constitution of the Republic of Latvia (direct legislation and President of Latvia)]. Tieslietu Ministrijas Vēstnesis, No. 4-6, 1921, pp. 142-143.

${ }^{143}$ Ūdris, J. Gunta Ulmaņa vertikāle [ Guntis Ulmanis’ Vertical]. Rìga: Jumava, 2009, p. 207. 
8. Dišlers, K. Ievads Latvijas valststiesību zinātnē [Introduction to Latvian State Law Science]. Rīga: Tiesu namu aǵentūra, 2017.

9. Dišlers, K. Latvijas Republikas Satversmes grozǐ̌̌anas kārtība [Procedures for amending the Satversme [Constitution] of the Republic of Latvia]. Tieslietu Ministrijas Vèstnesis, No. 7/8, 1929.

10. Dišlers, K. Negotiorium gestio publisko tiesību novadā [Negotiorium gestio in the Area of Public Law]. Tieslietu Ministrijas Vēstnesis, 1935.

11. Ekspertu komentāri Uzṇēmumu reg̣istra valsts notāres Lilitas Strodes 2013. gada 14. marta lēmumam Nr. 10-11/1850 [Expert comments to the Decision of the State notars of the Enterprise Register, Lilith Strodes, of 14 March 2013 No. 10-11/1850]. Jurista Vārds, No. 28, 23.04.2013.

12. Endziņš, A. Preambulas projekts var destabilizēt sabiedrību [The draft preamble could destabilize society]. Jurista Vārds, No. 44, 29.10.2013.

13. Jurista Vārda lasītāju aptaujas rezultāti [The results of a survey of readers]. Jurista Vārds, No. 43, 22.10.2013.

14. Kärklina, A. Requirements to be Set for Voters' Legislative Initiatives in the Republic of Latvia: Legal Regulation, Practice, and Recent Findings of Judicature. Journal of the University of Latvia. Law, No. 10, 2017.

15. Konstitucionālās tiesību komisijas 17.09.2012. viedoklis par Latvijas valsts konstitucionālajiem pamatiem un neaizskaramo Satversmes kodolu [Opinion by the Commission of Constitutional Law from 17.09.2012 on the Constitutional Foundations of the State of Latvia and Inviolable Core of the Satversme]. Available: http://blogi.lu.lv/tzpi/files/2017/03/17092012_Viedoklis_2.pdf [last viewed 04.09.2020].

16. Krüma, K., Plepa, D. Constitutional Law in Latvia. The Netherlands: Wolters Kluwer, 2016.

17. Kusiņš, G. Valsts iekārtas un tiesību sistēmas atjaunošana [Renewal of the national equipment and legal system]. In: Latvijas Valsts tiesību avoti. Valsts dibināšana - neatkarības atjaunošana. Dokumenti un komentāri. [Sources of Latvian State Law. Establishment of the state - restoration of independence. Documents and comments.] Rīga: Tiesu namu aǵentūra, 2015.

18. Kütris, G. Referendumi jeb tautas nobalsošanas: cik tas ir reāli [Referendums or the people's vote: How real is it]. Jurista Vārds, No. 42, 28.10.2014.

19. Latvijas Republikas Satversmes komentāri. Ievads. I nodaḷa. Vispārējie noteikumi [Comments of Satversme [Constitution]. Preamble. Section I. General rules]. Collective of authors, scientific ed. Prof. Balodis, R. Rīga: Latvijas Vēstnesis, 2014.

20. Latvijas Republikas Satversmes komentāri. II nodaḷa. Saeima [Comments of Satversme [Constitution]. Section II. Parliament]. Collective of authors, scientific ed. Prof. Balodis, R. Rìga: Latvijas Vēstnesis, 2020.

21. Latvijas Republikas Satversmes komentāri. V nodaḷa. Likumdošana [Comments of Satversme [Constitution]. Section V. Legislation]. Collective of authors, scientific ed. Prof. Balodis, R. Rīga: Latvijas Vēstnesis, 2019, pp. 205, 262-265.

22. Lazdiňs, J. Clashes of Opinion at the Time of Drafting the Satversme of the Republic of Latvia. Journal of the University of Latvia. Law, No. 10, 2017.

23. Levits, E. Eiropas Savienība kā vērtību savienība [The European Union as a union of values]. Jurista Vārds, No. 19, 08.05.2018.

24. Levits, E. Izvērstas Satversmes preambulas teksta piedāvājums un komentārs [Proposal and comment of the text of an expanded preamble to the Constitution]. Jurista Vārds, No. 39, 24.09.2013.

25. Levits, E. Valstsgriba. Idejas un domas Latvijai 1985-2018 [National will. Ideas and thoughts for Latvia 1985-2018]. Rīga: Latvijas Vēstnesis, 2019.

26. Meistere, D. Saeimas Juridiskā biroja atzinums par Satversmes ievada pieṇemšanas procedūru [Opinion of the Saeima Legal Office on the procedure for the adoption of the Constitution Preamble]. Jurista Vārds, No. 26, 08.07.2014.

27. Narits, R., Merusk, K. Constitutional Law. Estonia. The Hague, London, Boston: Kluwer, 1998.

28. Neatkarīgā Rìta Avīze, 04.07.1998.

29. Nikul̦ceva, I. Fakultatīvā tautas nobalsošana Latvijā un Eiropā [Optional National Referendums in Latvia and Europe]. Juridiskās zinātnes aktuālās problēmas. [Current challenges of legal science] Rìga: Zvaigzne ABC, 2012.

30. Nikuļceva, I. Tautas nobalsošana un vēlētāju likumdošanas iniciatīva. Promocijas darbs [Doctoral thesis "National Referendum and Voters' Legislative Initiative"]. Rìga: Latvijas Universitāte, 2012, p. 206. Available: https://dspace.lu.lv/dspace/bitstream/handle/7/5120/22881-Inese_ Nikulceva_2013.pdf?sequence=1 [last viewed 04.09.2020].

31. Nikuļceva, I. Tiešā demokrātija Eiropā [Direct democracy in Europe]. Jurista Vārds, No. 169, 26.10.2010. 
32. Ozoliňš, A. Vienotības piga [Vienotība cocking a snook]. Ir, 26.07.-01.08.2012.

33. Pamattiesības. Pilsonība. Latvijas Valsts tiesību avoti. Valsts dibināšana - neatkarības atjaunošana. Dokumenti un komentāri. [Fundamental rights. Nationality. Sources of Latvian State Law. Establishment of the state - restoration of independence. Documents and commentary]. Riga: Tiesu namu aǵentūra, 2015.

34. Paparinskis, M. Piezìmes par Satversmes preambulas projektu [Notes on the draft preamble to the Constitution]. Jurista Vārds, No. 43, 22.10.2013.

35. Parlamentārā izmeklēšana Latvijas Republikā. 1. parlaments. Parlamentārā kontrole [Parliamentary investigations in the Republic of Latvia 1. Parliament]. Scientific editor Prof. Balodis, R. Rīga: Latvijas Vēstnesis, 2016.

36. Pastars, E. Referendumu nedienas [Troubles with Referendums]. Diena, 03.08.2002.

37. Platace, L. Vēlētāju tiesības ierosināt referendumus pārmaiṇu priekšā [Voters right to propose referendums in front of change]. Available: https://lvportals.lv/norises/250193-veletaju-tiesibasierosinat-referendumus-parmainu-prieksa-2012 [last viewed 10.09.2020].

38. Pleps, J. Satversmes iztulkošana [Translating the Constitution]. Rīga: Latvijas Vēstnesis, 2012.

39. Pleps, J., Pastars, E., Plakane, I. Konstitucionālās tiesības [Constitutional law]. Supplemented and revised edition. Rīga: Latvijas Vēstnesis, 2014.

40. Priekšlikumi Latvijas publiskās varas pilnveidošanai [Proposals for improving the public power of Latvia]. Ekspertu grupas pārvaldības pilnveidei materiāli [Materials for improving the management of the expert group]. Rìga: Latvijas Vēstnesis, 2015.

41. Rodinga, A. Valstiskuma pamatu aizsardzības mehānismi [Mechanisms for Protecting the Foundations of Statehood]. Latvijas Universitātes 71. zinātniskās konferences rakstu krājums. Tiesību interpretācija un tiesību jaunrade - kā rast pareizo līdzsvaru [Mechanisms for Protecting the Foundations of Statehood]. Rīga: Latvijas Universitāte, 2013.

42. Saeima lems par Satversmes grozī̌anu sakarā ar Eiropas Savienību [Saeima will decide on amending the Constitution in connection with the European Union]. Jurista Vārds, No. 7, 18.02.2003.

43. Šiliņš, J. Padomju Latvija 1918-1919 [Soviet Latvia 1918-1919]. Rīga: Vēstures izpētes un popularizēšanas biedrība, 2013.

44. Taube, C. Constitutionalism in Estonia, Latvia and Lithuania. A study in comparative constitutional law. [S. L.]: Iustus Förlag AB, 2001, pp. 116-117.

45. Timofejevs, p. Referendumi un demokrātija [Referendums and democracy]. Diena, 13.09.2003.

46. Unconstitutional Constitutional Amendments. The Limits of Amendment Powers. Edited by Loughlin, M., McCormick, J. P., Walker, N. United Kingdom: Oxford University Press, 2017.

47. Üdris, J. Gunta Ulmaņa vertikāle [Guntis Ulmanis' Vertical]. Rīga: Jumava, 2009.

48. Valdības deklarācijas [Government declaration]. Valdības Vēstnesis, No. 10, 19.05.1934.

49. Vanags, K. Latvijas valsts Satversme [The Constitution of the State of Latvia]. Valka: L. Rumaka apgāds, 1948.

50. Viedokḷu diskusija: Valsts pamati - vai visiem pašsaprotami [Discussion of views - understandable for everyone]. Jurista Vārds, No. 45, 06.11.2012.

\section{Normative Acts}

1. Latvijas Republikas Satversme [Satversme [Constitution] of the Republic of Latvia] (15.02.1922). Valdības Vēstnesis, No. 141, 1922.

2. Tautas padomes politiskā platforma [Political platform of the People's Council]. Adopted at the meeting of the People's Council of Latvia (17.11.1918). Valdïbas Vèstnesis, No. 1, 14.12.1918.

3. Latvijas pilsoṇiem!: Tautas Padomes Latvijas Republikas proklamēšanas akts [For Latvian citizens!: Proclamation Act of the People's Council of Latvia] (18.11.1918). Latvijas Pagaidu Valdības Likumu un Rìkojumu Krājums, No. 1, 15.07.1919.

4. Deklarācija par Latvijas valsti: Latvijas Satversmes Sapulces deklarācija [Declaration on the State of Latvia] (27.05.1920). Likumu un Valdības Rīkojumu Kräjums, No. 4, 31.08.1920.

5. Latvijas valsts pagaidu iekārtas noteikumi [Regulations of the Latvian State Interim Facility] Adopted at the meeting of the Latvian Constituion Assembly (01.06.1920). Likumu un Valdibas Rìkojumu Krājums, No. 4, 31.08.1920.

6. Par Latvijas Republikas neatkarības atjaunošanu: Augstākās padomes deklarācija [On the restoration of independence of the Republic of Latvia] (04.05.1990). Latvijas Republikas Augstākās Padomes un Valdības Ziņotājs, No. 20, 17.05.1990.

7. Par Latvijas Republikas valstisko statusu: konstitucionālais likums [On the State Status of the Republic of Latvia: Constitutional Law] (21.08.1991). Latvijas Republikas Augstākās Padomes un Valdības Ziṇotājs, No. 42, 24.10.1991. 
8. Latvijas Republikas Saeimas pazinojums [Statement by the Saeima of the Republic of Latvia]. Latvijas Republikas Saeimas un Ministru Kabineta Zinotājs, No. 30, 14.10.1993.

9. Par tautas nobalsošanu, likumu ierosināšanu un Eiropas pilsoņu iniciatīvu: LR likums [Law on National Referendums, Initiation of Laws and European Citizens' Initiative: Law of the Republic of Latvia]. Latvijas Vēstnesis, No. 47, 20.04.1994.

10. Saeimas kārtibas rullis: LR likums [The Rules of Procedure of the Saeima: Law of the Republic of Latvia]. Latvijas Vēstnesis, No. 96(227), 18.08.1994.

11. Grozijjumi likumā "Par tautas nobalsošanu, likumu ierosināšanu un Eiropas pilsoṇu iniciatīivu": LR likums [Amendments to "Law on National Referendums, Initiation of Laws and European Citizens' Initiative": Law of the Republic of Latvia] (08.11.2012). Latvijas Vēstnesis, No. 186(4789), 27.11.2012.

\section{Case Law}

1. Judgment of 29 November 2007 by the Constitutional Court in case No. 2007-10-0102.

2. Judgment of 16 December 2008 by the Constitutional Court in case No. 2008-09-0106, para. 16.5.

3. Judgment of 7 April 2009 by the Constitutional Court in case No. 2008-35-01.

4. Judgment of 18 April 2019 by the Constitutional Court in case No. 2018-16-03.

5. Judgment of 24 October 2019 by the Constitutional Court in case No. 2018-23-03.

6. Latvijas Republikas Augstākās tiesas Senāta Administratīvo lietu departamenta 30.04.2013. spriedums lietā SKA-172/2013 [Decision of 30 March 2013 by the Senate of the Supreme Court of the Republic of Latvia in case SKA-172/2013]. Available: at.gov.lv/files/files/ [last viewed 13.09.2020].

7. Augstākās tiesas Administratīvo lietu departamenta 12.02.2014. sprieduma lietā Nr. A420577912 SA-1/2014 motivu dalias 12. punkts [Decision of 12 February 2014 by the Supreme Court of the Republic of Latvia in case No. A420577912 SA-1/2014]. Available: at.gov.lv/files/files/ [last viewed 13.09.2020].

8. Augstākās tiesas Administratīvo lietu departamenta 28.03.2014. sprieduma lietā SA-3/2014 motīvu daļas 12. punkts [Decision of 28 March 2014 by the Supreme Court of the Republic of Latvia in case SA-3/2014]. Available: at.gov.lv/files/files/ [last viewed 13.09.2020].

9. Satversmes tiesas tiesneša Jura Jelāgina 2009. gada 21. aprịla atsevišķāa domas lietā Nr. 2008-3501 [Separate thoughts of the Constitutional Court Judge Juris Jelāgins in case No. 2008-35-01 of 21 April 2009]. Available: https://juristavards.lv/doc/194927-satversmes-tiesas-tiesnesa-jurajelagina-atseviskas-domas/ [last viewed 04.09.2020].

\section{Transcripts}

1. Rainis, J. Vispārējās debates par Satversmes I daḷu. IV sesijas 5. sēdes (1921. gada 28. septembrī) stenogramma [Transcript of the $5^{\text {th }}$ sitting of the IV Session of the Constitutional Assembly 28.09.1921]. In: Latvijas Satversmes sapulces stenogrammu izvilkums (1920-1922). Latvijas Republikas Satversmes projekta apspriešana un apstiprināšana [Discussion and approval of the draft Constitution of the Republic of Latvia] Rīga: Tiesu namu aǵentūra, 2006.

2. Satversmes I daḷas lasǐšana pa pantiem. IV sesijas 20. sēdes (1922. gada 9. novembrī) stenogramma [Transcript of the $20^{\text {th }}$ sitting of the IV Session of the Constitutional Assembly 09.11.1922]. In: Latvijas Satversmes sapulces stenogrammu izvilkums (1920-1922). Latvijas Republikas Satversmes projekta apspriešana un apstiprināšana [Discussion and approval of the draft Constitution of the Republic of Latvia]. Riga: Tiesu namu aǵentūra, 2006.

3. Satversmes I daḷas lasī̌̌ana pa pantiem. V sesijas 14. sēdes (1922. gada 15. februārī) stenogramma. [Transcript of the $14^{\text {th }}$ sitting of the V Session of the Constitutional Assembly 15.02.1922]. In: Latvijas Satversmes sapulces stenogrammu izvilkums (1920-1922). Latvijas Republikas Satversmes projekta apspriešana un apstiprināšana [Discussion and approval of the draft Constitution of the Republic of Latvia]. Rìga: Tiesu namu aǵentūra, 2006.

4. Latvijas Republikas IV Saeimas V sesijas 3. sēdes (1933. gada 7. februārī) stenogramma [Transcript of the $3^{\text {th }}$ sitting of the V Session of the Latvian IV Saeima [Parliament] 07.02.1933]. In: Latvijas Republikas IV Saeimas V sesija. 1933. gads [V Session of the Latvian IV Saeima [Parliament]]. Riga: Latvijas Republikas Saeimas izdevums, 1933.

5. Latvijas Republikas IV Saeimas V sesijas 4. sēdes (1933. gada 10. februārī) stenogramma [Transcript of the $4^{\text {th }}$ sitting of the V Session of the Latvian IV Saeima [Parliament] 10.02.1933]. In: Latvijas Republikas IV Saeimas V sesija. 1933. gads [V Session of the Latvian IV Saeima [Parliament\}]]. Riga: Latvijas Republikas Saeimas izdevums, 1933. 
6. Latvijas Republikas IV Saeimas V sesijas 10. sēdes (1933. gada 10. martā) stenogramma [Transcript of the $10^{\text {th }}$ sitting of the V Session of the Latvian IV Saeima [Parliament] 10.03.1933]. In: Latvijas Republikas IV Saeimas V sesija. 1933. gads [V Session of the Latvian IV Saeima [Parliament]]. Rīga: Latvijas Republikas Saeimas izdevums, 1933.

7. Latvijas Satversmes sapulces Satversmes komisijas 1. apakškomisijas 1921. gada 17. janvāra sēdes protokols Nr. 8 [Minutes of the Constitutional Assembly Constitutional Commision, the $1^{\text {st }}$ subcommission meeting 17.01.1921]. Unpublished source.

8. Satversmes izstrādes komisijas 1921. gada 6. aprīla sēdes protokols [Minutes of the Constitutional Assembly Constitutional Commision meeting 06.04.1921]. Unpublished source.

\section{Other Sources}

1. Bulgarian Constitution. Available: https://www.constituteproject.org/constitution/Bulgaria_2015?1 ang=en [last viewed 04.09.2020].

2. Croatia's Constitution. Available: https://www.constituteproject.org/constitution/Croatia_2013? lang=en [last viewed 04.09.2020].

3. Estonian Constitution. Available: https://www.constituteproject.org/constitution/Estonia_2015. pdf?lang=en [last viewed 04.09.2020].

4. Constitution of the German Reich August 11.1919. Available: http://hydrastg.library.cornell.edu/ fedora/objects/nur:01840/datastreams/pdf/content [last viewed 10.09.2020].

5. French Constitution. Available: https://www.constituteproject.org/constitution/France_2008? lang=en [last viewed 04.09.2020].

6. Italian Constitution. Available: https://www.constituteproject.org/constitution/Italy_2012? lang=en [last viewed 04.09.2020].

7. Lithuanian Constitution. Available: https://www.constituteproject.org/constitution/Lithuania_ 2006?lang=en [last viewed 04.09.2020].

8. 2018. autumn. Public opinion in the European Union Standard Eurobarometer 90. Available: file://C:/Users/User/AppData/Local/Temp/eb_90_data_annex_en.pdf https://ec.europa.eu/malta/sites/default/files/st90-report.pdf [last viewed 04.09.2020].

9. Sabiedrības apmierinātība ar pašreizējo vēlēšanu sistēmu varētu būt samazinājusies [Public satisfaction with the current electoral system could have abated]. LETA. Available: https:// www.apollo.lv/5299562/sabiedribas-apmierinatiba-ar-pasreizejo-velesanu-sistemu-varetu-butsamazinajusies [last viewed 04.09.2020]. 